\title{
29. EVOLUTION OF THE SOUTHWESTERN ATLANTIC OCEAN BASIN: RESULTS OF LEG 36, DEEP SEA DRILLING PROJECT
}

\author{
The Shipboard Scientific Party' Together with Wayne Harris, and William V. Sliter
}

\section{INTRODUCTION}

Leg 36 started in Ushuaia, Argentina, on 4 April 1974 and finished in Rio de Janeiro, Brazil, on 22 May 1974. It completed the second of three austral summer seasons of drilling planned for Antarctic waters during Phase III of the Deep Sea Drilling Project. In fact Leg 36 brought the Antarctic drilling program of Phase III to an end, because the plan to drill south of Africa during the austral summer of 1974-75 had to be abandoned for want of a suitable escort vessel.

The two main objectives of Leg 36 as originally conceived by the Antarctic Advisory Panel were to investigate the geologic histories of the Scotia Arc and of the Argentine Basin.

Weather conditions and icebergs forced complete mid-cruise modifications of the Leg 36 scientific program as originally planned. They even played havoc with the modified program so that only 2 of the 10 holes spudded were voluntarily abandoned with all the scientific objectives achieved. The cruise track and site locations are shown in Figure 1.

Despite the problems we drilled 10 holes at six sites with a total penetration of 2481 meters and recovered 580 meters of 1007 meters cored ( $57.6 \%$ recovery). Data from four of the sites-327, 329, and 330 on the Falkland (Malvinas) Plateau and 328 in the Malvinas Outer Basin-constitute a major contribution to knowledge of the tectonic and oceanographic evolution of the southernmost Atlantic Ocean Basin (Table 1).

\section{Summary of Results}

Site 326 , drilled in a sediment pod on the oceanic crust generated at a northeast-southwest-trending spreading center in Drake Passage, and Site 331, in the Argentine Basin, resulted in the recovery of surface

\footnotetext{
'Peter Barker (Co-chief scientist), The University of Birmingham, Birmingham, England; Ian W.D. Dalziel (Co-chief scientist), Lamont-Doherty Geological Observatory, Palisades, New York; Menno G. Dinkelman, The Florida State University, Tallahassee, Florida; David H. Elliot, The Ohio State University, Columbus, Ohio; Andrew M. Gombos, Jr., The Florida State University, Tallahassee, Florida; Alberto Lonardi, CONICET, Buenos Aires, Argentina; George Plafker, U.S. Geological Survey, Menlo Park, California; John Tarney, University of Birmingham, Birmingham, England; Robert W. Thompson, Humboldt State College, Arcata, California; R.C. Tjalsma, Woods Hole Oceanographic Institution, Woods Hole, Massachusetts; Christopher C. von der Borch, The Flinders University, Bedford Park, South Australia; Sherwood W. Wise, Jr., The Florida State University, Tallahassee, Florida.
}

cores only and will be considered only briefly here. The four successful sites of the leg were drilled on the Falkland (Malvinas) Plateau and in the Malvinas Outer Basin. The Falkland Plateau extends eastwards from the continental shelf of the South American continent (Figure 1). The 500-fathom submarine contour lies east of the Falkland Islands which consist of a metamorphic complex overlain by Paleozoic-Triassic sedimentary strata deformed in the early Mesozoic and cut by mafic dykes (Greenway, 1972). The strata can be correlated with rocks of comparable age in South America and southern Africa. There is therefore no reason to doubt that the western portion of the plateau at least is underlain by continental crust. It has been treated in this way in considering the geometric "fit" of South America and Africa (Bullard et al., 1965). The eastern prolongation of the Falkland (Malvinas) Plateau, however, lies at considerably greater depths, and although it has been considered to be floored by continental basement (Ewing et al., 1971), this could not be proved, particularly since DSDP Site 249 on the Mozambique Ridge, which adjoins it in continental reconstructions, terminated in tholeiitic basalt. The Malvinas Outer Basin is part of the floor of the South Atlantic Ocean Basin. At the time of Leg 36 magnetic anomalies in the basin had not been identified.

A brief summary of the principal findings at each site is given below. A lithostratigraphic correlation diagram is shown in Figure 2.

Site 326 (Drake Passage) was drilled in 3812 meters of water about $150 \mathrm{~km}$ southeast of Cape Horn. Our main objective here was to check the magnetic-reversal dating of the opening of Drake Passage by determining basement age. Unfortunately, we obtained only one core before the very bad weather, strong currents, and loss of 3800 meters of drill pipe caused us to abandon the site.

Site 327 , in 2400 meters of water on the western nose of the elevated eastern part of the Falkland Plateau, the Maurice Ewing Bank, was chosen to examine Southern Ocean shallow-water pre-Neogene biostratigraphy and to identify seismic reflectors of regional extent. The first hole was abandoned in bad weather after recovery of only a surface core, but the second hole was cored continuously to 113 meters and intermittently to 469.5 meters before also being abandoned due to excessive ship motion. Twenty-eight cores were taken, with $50 \%$ recovery. Ten meters of Quaternary ice-rafted terrigenous debris with manganese nodules overlie a sequence of mid-Paleocene to lower Eocene alternating siliceous ooze and zeolitic clay 80 meters thick. 


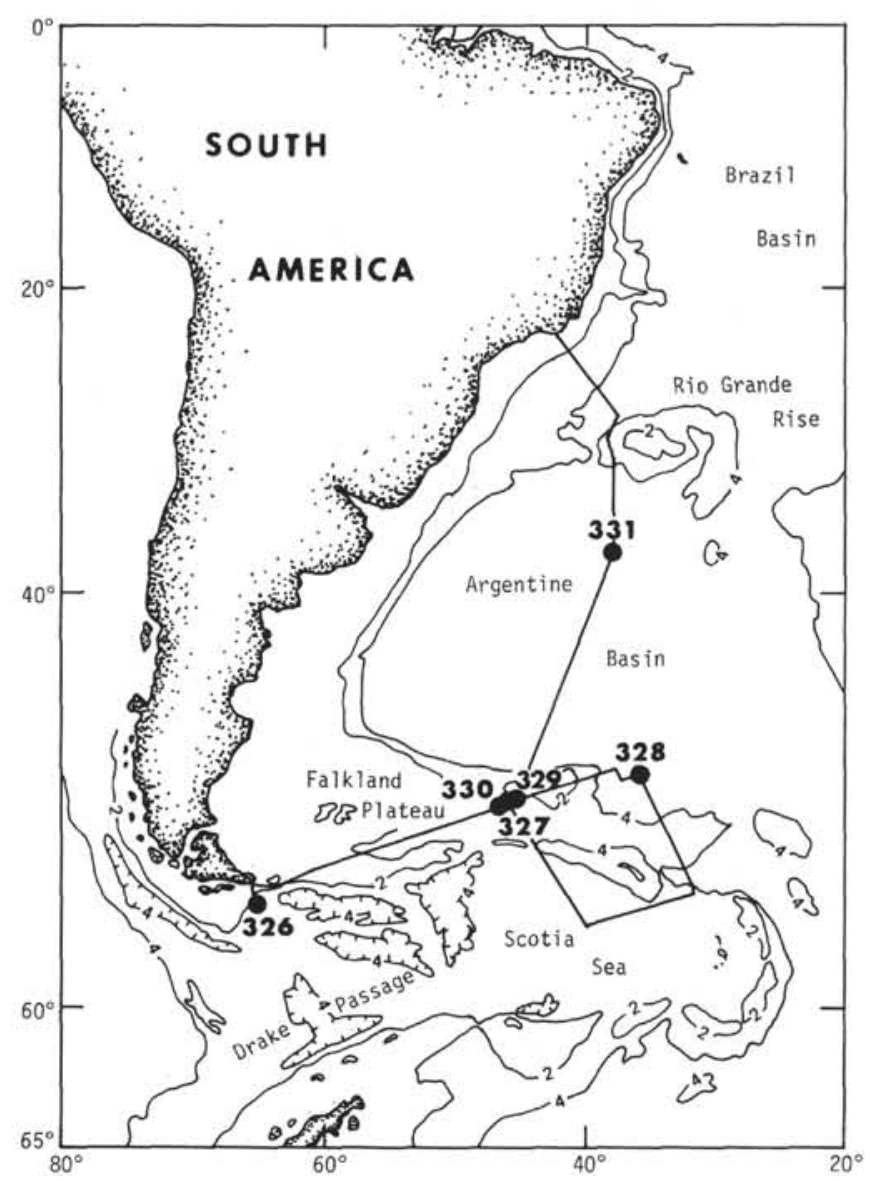

Figure 1. Bathymetry of the southwestern Atlantic Ocean basin and location of Leg 36 sites.

Hiatuses occur above this sequence (Eocene to Quaternary) and below (late Maestrichtian to mid-Paleocene). Below 52 meters of Maestrichtian foram-nanno ooze lies a condensed section, up to 12 meters, of Santonian zeolitic clay with probably a Turonian-Coniacian hiatus. Below 154 meters subbottom, about 170 meters of a mostly Albian nanno claystone (uppermost part is Cenomanian) overlies an Aptian to ?Neocomian sapropelic claystone which extends to the base of the hole. Thus, restricted circulation in Aptian times gave way to more open ocean conditions in the Albian, following the development of a deep-water connection between the Atlantic and Indian oceans as the Falkland Plateau cleared southern Africa. Subsidence and improved circulation followed, with the CCD largely above the sea bed at the site. Possible Late Cretaceous, and very probable Neogene, submarine erosion resulted from changes in circulation patterns, the latter possibly consequent upon opening of Drake Passage 20 to $30 \mathrm{~m} . y$. ago. Cores contain unique siliceous flora and fauna at the Paleocene-Eocene boundary, with many new forms, and excellently preserved Maestrichtian calcareous fossils. Hole 327A penetrated about half of the sedimentary cover at the site.

Site 328 , in 5103 meters of water in the Malvinas Outer Basin immediately to the east of the Falkland
Plateau and to the south of the Falkland Fracture Zone, was chosen to examine correlatives of Argentine Basin acoustic reflectors, to obtain a deep-water southerly biostratigraphic section, and if possible, to date the underlying oceanic basement. Three holes were drilled at the site. The deepest penetrated 471 meters and bottomed in Upper Cretaceous gray zeolitic claystone.

The top 13.5 meters consists of late Miocene-Quaternary diatomaceous ooze with abundant manganese nodules, sand, and large clasts. The lithology of these presumably ice-rafted clasts does not identify a specific source area. All are found around the Weddell Sea margin and the Antarctic Peninsula. The underlying 34 meters of silty, biogenic siliceous clay is of late Eocenelate Miocene age. Below this sediment Upper Cretaceous or Paleocene-upper Eocene siliceous clay and claystone extends to about 300 meters subbottom. The remainder of the section consists of Upper Cretaceous zeolitic claystone.

The reflector correlated with Horizon "A" of the Argentine Basin appears to represent a gradual diagenetic change from clay to claystone rather than a distinctive lithic layer. Extrapolation of sedimentation rates suggests that the uncored acoustic basement is of Albian age. The relatively high rate of sedimentation represented by the Upper Cretaceous-upper Eocene clay and claystone is believed to have been related to the mid-Cretaceous uplift of the Andean cordillera. A substantial reduction in sedimentation rate, decrease in clay content, and major breaks in the stratigraphic record indicate increase in bottom current velocity in the late Eocene continuing through the Miocene. Cold water microfossils become dominant in the middle Miocene, and certain ice-rafted material appears in the late Miocene.

Site 329 , in 1519 meters of water some $55 \mathrm{~km}$ northeast of Site 327 on the Maurice Ewing Bank, was chosed to obtain the shallow-water Neogene biostratigraphic section deliberately avoided at the earlier site. The single hole was cored continuously to 179.5 meters and intermittently to 464.5 meters, yielding 33 cores with $69 \%$ recovery and bottoming in Paleocene nanno chalk. It thus provides some stratigraphic overlap with the section cored at Site 327.

Apart from ice-rafted terrigenous debris in the uppermost 4.5 meters of Quaternary diatomaceous ooze, the entire section is biogenic. About 220 meters of upper Miocene nanno and diatom ooze overlies 125 meters of more consolidated middle to upper Miocene ooze and chalk. Beneath this, a Paleocene to lower or middle Miocene nanno chalk, locally silicified, extends to the base of the hole. The sedimentation rate is about five times as high in the uppermost 350 meters of Miocene sediments as in the older sediments beneath. Hiatuses probably span the late Oligocene and early Miocene, and the middle to early Eocene. The former represents an unconformity which reflection profiles show to form the base of a $100-\mathrm{km}$-long bank of Miocene oozes. This and the presence of reworked Oligocene fossils in the Miocene sediments indicate that strong bottom currents swept the region in the 

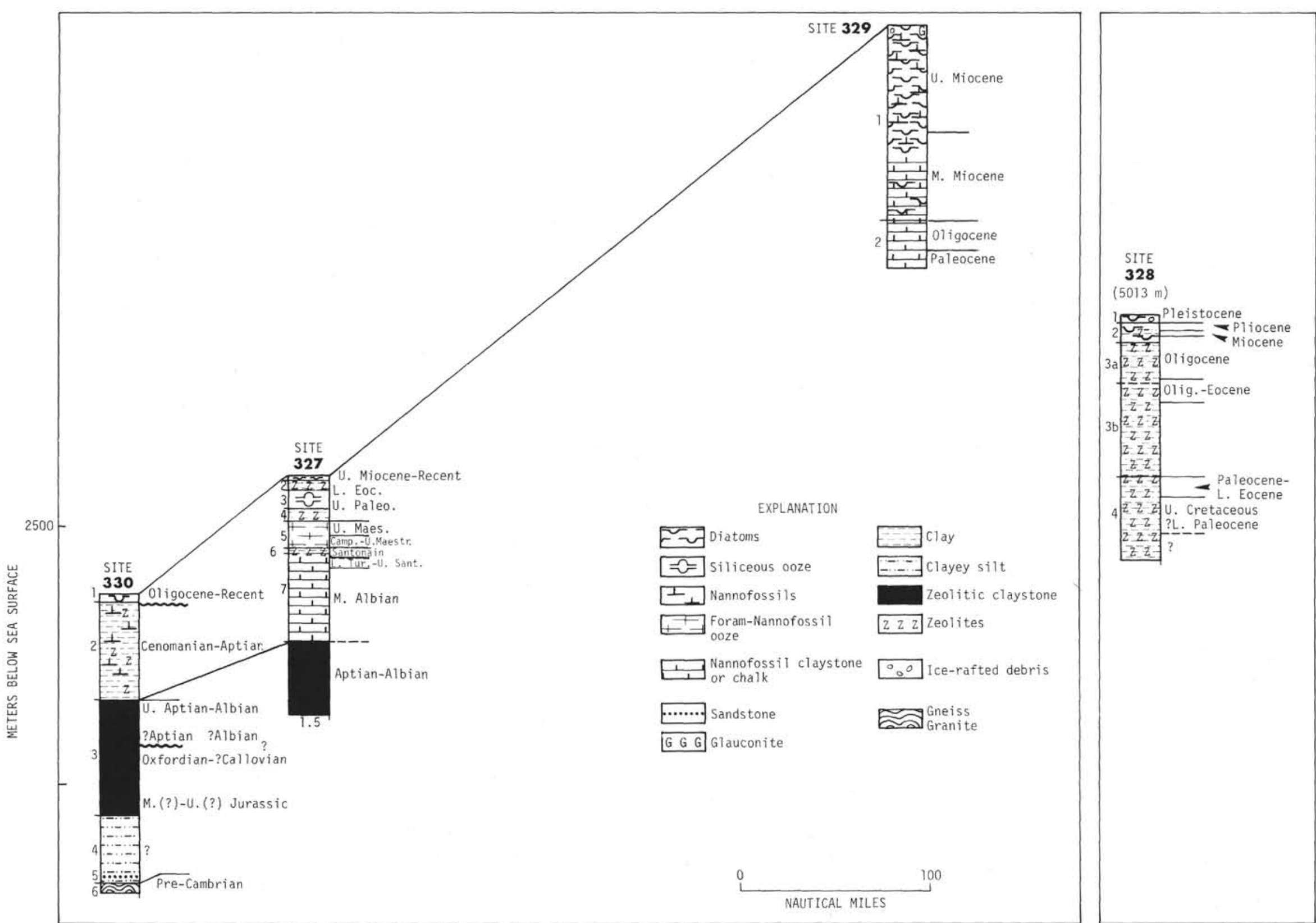
Neogene, probably as a result of the opening of Drake Passage.

Site 330, in 2626 meters of water at the western end of the elongate rise forming the eastern end of the Falkland Plateau, the Maurice Ewing Bank, was selected to elucidate the pre-Aptian history of the Falkland Plateau and to obtain a biostratigraphic section older than that cored at Sites 327 and 329. Two holes were drilled, the deepest penetrating gneissose and granitic continental basement at 550 meters subbottom.

Silty clay and ooze containing Eocene to Oligocene and Recent diatoms were recovered above 34 meters. At this level 166 meters of Albian-Cenomanian zeoliterich nanno clay was penetrated. The clay overlies 225 meters of sapropelic claystone which extends to 425 meters subbottom. This claystone contains Oxfordian and Aptian fossils. A drastic reduction in sedimentation rate, non deposition, or even erosion must have taken place even allowing for a 19-meter coring gap. Beneath the sapropelic claystone is 115 meters of Oxfordian interbedded silty clay and clayey silt with layers of sandstone and limestone. A terrigenous source is apparent for these sediments which overlie a subarkosic sandstone at least $20 \mathrm{~cm}$ thick, thought to be a beach sand reflecting a basal marine transgression. The underlying siltstone and sandstone contain lignite interbeds and indicate fluviatile deposits. These sediments are 3 meters thick, extending from 547 to 550 meters subbottom. At 550 meters they unconformably overlie the gneissose and granitic basement of which 19.5 meters were cored. The top of the basement has been calcretized.

The basement rocks were clearly part of an extensive continental igneous and metamorphic complex of Precambrian age affected by thermal events at various times during the Paleozoic. This is in keeping with their regional setting prior to the opening of the South Atlantic Ocean, The calcrete formation suggests alteration of the basement under Mediterranean-type climatic conditions prior to the deposition of the overlying nonmarine Jurassic sediments. The sedimentary succession indicates a subsequent history of midlate Jurassic (probably Oxfordian) marine transgression, a period of restricted circulation until the end of the Aptian, establishment of open marine conditions by the early Albian, and subsidence to the present depth of the site during the Late Cretaceous and Paleogene.

At Site 331 (Argentine Basin), to our great regret, a combination of bad weather-both experienced and forecast - and damage to the drill rig caused us to abandon the hole after penetrating only 18 meters in 4 days of drilling. None of the major goals was achieved.

The recovered sediment consists of lower Pleistocene diatomaceous clay with quartz-silt layers, containing large and robust diatoms and radiolarians endemic to cool, circumpolar waters as well as more temperate forms, suggesting transport of Antarctic Bottom Water. However, some brackish-water diatoms, together with the coarse fraction and heavy minerals in the silt and sandy silt layers, are more probably derived from the continental margin of South America.

\section{THE BASEMENT AND PREDRIFT SETTING OF THE FALKLAND PLATEAU}

The geologic relations of South America and Africa prior to continental drift are well established. Modern studies of the configuration of the continental margins, marine magnetic anomalies, geology, and the geochronology of the Brazilian-Guianean and West African shields (Bullard et al., 1965; Smith and Hallam, 1970; Hurley et al., 1967; Ladd et al., 1973) support the classical work of Du Toit (1937). For the well-known geometric fit of the two continents computed by Bullard et al. (1965), the continental margin was taken to be the 500 -fathom bathymetric contour. On the South American side this contour lies directly east of the Falkland Islands (Figure 1). The physiography of the Falkland Plateau, the continental geology of the Falkland Islands (Baker, 1924; Greenway, 1972), and seismic refraction data (Ewing et al., 1971) all suggest that the eastern extremity of the plateau, the Maurice Ewing Bank, forms part of the South American continent. However, because the depth of this extremity considerably exceeds that of most continental areas, generally it has not been taken into account in continental reconstruction.

With confirmation of the continental nature of the crust underlying the easternmost part of the Falkland Plateau provided by the gneissose and granitic basement rocks cored at Site 330, a more detailed geometric reconstruction of southern Africa and southeastern South America is justifiable (Figures 3 and 6), and it is possible to consider the geologic setting of the plateau prior to the deposition of the upper Mesozoic sediments overlying the basement at that site.

The metamorphic and igneous basement recovered at Site 330 has a long history (Tarney, this volume). With such a small sample of a complex of this type, and particularly in the absence of structural data, it is impossible to correlate exactly the basement of the eastern Falkland Plateau with exposed rocks on the adjacent continents. However, the radiometric date of $535 \pm 66$ m.y. obtained by $\mathrm{Rb}-\mathrm{Sr}$ whole-rock analysis of the metasedimentary basement rocks at Site 330 is comparable to the reported age of the granitic rocks near the Cape of Good Hope in Africa (Allsopp and Kolbe, 1965; Beckinsale et al., this volume). The nearest basement exposed on the South American continent is the pre-Paleozoic rock at Cape Meredith on West Falkland (Figure 1). Rb-Sr and K-Ar ages of approximately 1000 m.y. have been obtained from gneiss, granitic rock, and amphibolite samples from the Cape Meredith complex, and $\mathrm{K}-\mathrm{Ar}$ ages of 500-554 m.y. have been obtained from lamprophyre dykes (Cingolani and Varela, in press). A metamorphic complex of comparable age crops out on the southeast coast of Africa near Durban (Haughton, 1969). In all probability the $535 \mathrm{~m} . \mathrm{y}$. date on the gneiss at Site 330 represents a metamorphic event and the rocks themselves are still older, i.e., Precambrian (Beckinsale et al., this volume). Hence the samples of basement obtained from the eastern part of the Falkland Plateau are broadly comparable in age as well as lithology to the exposed basement rocks of the 

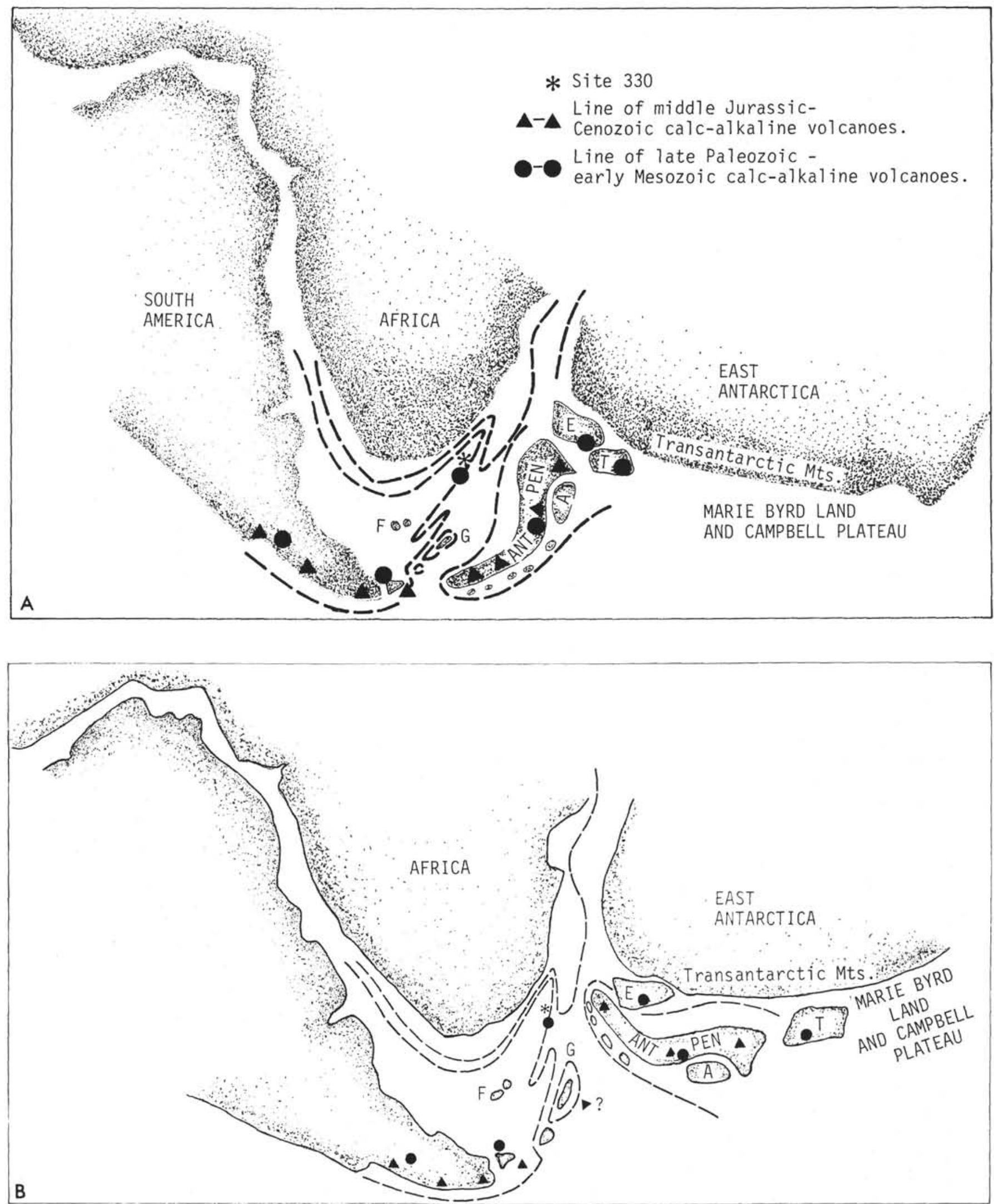

Figure 3. Two alternative reconstructions of Gondwanaland in the vicinity of Leg 36 sites. A = Alexander Island, ANT PEN $=$ Antarctic Peninsula, $E=$ Ellsworth Mountains microplate, $F=$ Falkland Islands, $G=$ South Georgia microplate, $T=$ Thurston Island microplate. Figure $3 a$ is the preferred reconstruction of de Wit (in press). 
adjoining areas of the African and South American continents. This appears to confirm provenance studies on sedimentary rocks in southern Africa that indicate basement rocks comparable to those exposed on that part of the continent existed to the southeast during the late Permian to early Triassic (Theron, 1975).

An important consideration in the geotectonic setting of the sites drilled by Leg 36 on the Falkland Plateau and in the Malvinas Outer Basin is the original position of Antarctica relative to South America and Africa. Whereas the predrift relations of the latter two continents and of Australia and East Antarctica are well established (Bullard et al., 1965; Weissel and Hayes, 1972), the relative positions of East and West Antarctica and of both of these parts of the Antarctic continent to Africa and South America are still the subject of considerable debate.

Two main reasons exist for believing that the East Antarctic craton lay to the east (present coordinates) of South Africa and that the Andean-West Antarctic Cordillera lay to the south and southeast, as shown in both possible reconstructions discussed here (Figure 3). Firstly, the early Mesozoic (Gondwanide) foreland fold belt continues through southern Africa from the Sierra de la Ventana of Argentina to the Transantarctic Mountains which border the craton between the Weddell and Ross seas (Du Toit, 1937; Craddock, 1964, 1974; Elliot, 1972, 1975). Secondly, calcalkaline volcanic detritus derived from the south was deposited in the Karroo Supergroup rocks of South Africa during the late Paleozoic and earliest Mesozoic (Fuller, 1974; Elliot and Watts, 1974; Martin, 1974). This material must have been derived from an active andesitic volcanic chain. No such chain is present in the East Antarctic craton or along the Transantarctic Mountains. One does appear to have existed, however, along the eastern side of the Andean Cordillera in South America, and in West Antarctica (Halpern, 1972; Dalziel et al., 1975b; de Wit, in press). This implies that the Andean-West Antarctic Cordillera, rather than the East Antarctic craton, was the part of Gondwanaland which lay south and east of the Maurice Ewing Bank prior to breakup of the supercontinent. The exact paleogeographic configuration of the part of the continental margin in question is not known, hence two of the more attractive alternatives are presented here (Figure 3).

Metamorphic rocks from the pre-Middle Jurassic continental basement of South America extend as far south as the Beagle Channel (Dalziel and Cortés, 1972; Dalziel et al., 1975a). These rocks probably underlie the north Scotia Ridge at least as far as the eastern limit of Burdwood Bank (Ludwig et al., 1968; Dalziel et al., 1974a). It has long been recognized that the southern Andes are geologically comparable to the Antarctic Peninsula (Barrow, 1831; Arctowski, 1895). Recent field work has revealed that the pre-Middle Jurassic basement of the peninsula and offshore islands is lithologically and structurally identical to that in southern South America (Dalziel and Elliot, 1971, 1973; Dalziel et al., 1975b; de Wit, in press). Moreover, the basement rocks can be interpreted to represent both. the uplifted and eroded roots of a late Paleozoic-early Mesozoic calcalkaline volcanic chain as mentioned above, and also the remnants of an arc-trench gap which existed on the Pacific side of that chain (Dalziel et al., 1975b; Smellie and Clarkson, 1975; Dalziel, in press; Rivana and Cortéz, 1976; Suarez, 1976). Therefore, irrespective of the reconstruction favored, prior to the breakup of "West" Gondwanaland (Africa-South America) in the Cretaceous, the Falkland Plateau was bounded to the south and east by basement representing a late Paleozoic-early Mesozoic continental margin volcanic arc and arc-trench gap. The $287 \pm 7$ m.y. age obtained on an intrusive from the basement at Site 330 (Beckinsale et al., this volume) indicates that at least limited thermal effects of this igneous activity may have affected the rocks of the plateau on the continental side of the arc.

\section{INITIAL BREAK-UP OF GONDWANALAND: SUBSIDENCE AND RESTRICTED CIRCULATION ON THE FALKLAND PLATEAU}

The Jurassic-Lower Cretaceous sedimentary sequences penetrated at Sites 327 and 330 on the Maurice Ewing Bank at the eastern extremity of the Falkland Plateau indicate that following the latest metamorphism of the gneissose and granitic basement the latter was uplifted, weathered (possibly in arid conditions at first), and eroded prior to the deposition of subaerial sediments in the ?Middle to Late Jurassic. The uplift was probably related to the early Mesozoic deformation known as the Gondwanide folding (or Gondwanian orogeny) which resulted in the formation of the Cape fold belt in South Africa, the Sierra de la Ventana in Argentina, and the Ellsworth and Pensacola fold belts in Antarctica behind the Pacific margin volcanic chain (Du Toit, 1937; Dalziel and Elliot, 1973).

In South Africa the Gondwanide deformation resulted in the formation of local bedrock basins, in synclines, which were infilled and aggraded by sediment derived from the local bedrock highs formed by the anticlines (Dingle, 1973).

Interpretation of the reflection profile through the Falkland Plateau sites shows that the basement at Site 330 forms a local high, at least along the line of section (Figure 4 and Barker, this volume). The basal ?Middle to Upper Jurassic sediments cored at Site 330 are characteristic of a swampy, possibly deltaic, coastal plain environment (Thompson, this volume). A marine transgression occurred in ?Middle-Upper Jurassic time as evidenced by beach sand which is overlain by marine silts and clays representing a shelf type of environment. Both the rough basement and the overlying shelf sediments slope gently up to the northeast, but they dip more steeply southwestward to a basin province which occupies the entire central part of the Falkland Plateau between the Maurice Ewing Bank and the Falkland Islands (Barker, this volume). Since the overlying reflectors show no signs of later faulting (Figure 4), Barker believes that the floor of the basin province lay 1-2 $\mathrm{km}$ below sea level at the time of the marine transgression at Site 330. The basin is considered to overlie continental crust. 
Beginning in Late Jurassic (Oxfordian) time and lasting into the Early Cretaceous (Aptian), euxinic conditions prevailed on the eastern Falkland Plateau with the accumulation of olive-black carbonaceous clays. As illustrated in Figure 4, no barriers existed between the Maurice Ewing Bank and the basin province of the Falkland Plateau (Barker, this volume). The restricted conditions at the site may therefore have obtained over much of the plateau as well as southern South America where comparable conditions existed during this time interval in the Magallanes Basin, the landward extension of the Falkland Trough (Natland et al., 1974; see Figure 8). However, some circulation of Pacific water on the plateau is indicated by the Indo-Pacific affinities of the marine fauna (Jones and Plafker, this volume).

The boundary between Oxfordian-Kimmeridgian and Neocomian-Aptian sediments at Site 330 lies in an uncored interval of only 25 meters. The uniform euxinic conditions that preceded and followed this break argue for extremely low sedimentation rates on the south side of the eastern Falkland Plateau during the interval involved rather than an unconformity due to uplift and subaerial erosion.

The apparent hiatus spans the time of initial opening of the South Atlantic Ocean Basin (Larson and Ladd, 1973). The marine transgression preceding this break can be traced down the east coast of Africa and on Madagascar. According to Kent (1974), marine conditions have been recorded in the Lower Jurassic of the coasts of Kenya, Tanzania, and western Madagascar, and in the Upper Jurassic of Mozambique and South Africa. Unlike the ?Middle to Upper Jurassic fauna of the eastern Falkland Plateau, the faunas of southeastern Africa, eastern Africa, and Madagascar have Tethyan affinities (Jones and Plafker, this volume). It therefore seems likely that the south side of the eastern Falkland Plateau with its Indo-Pacific fauna was isolated topographically from the Tethyan waters transgressing south along the eastern side of the African continent. Possibly the basement high of the plateau itself formed a barrier. At the same time the developing rift down the eastern side of Africa and into the South Atlantic area would have acted as a trap for land-derived sediment from Africa. Since the plateau would have constituted a far less extensive source of detritus, the rift could explain the low sedimentation rates on the south side of the plateau.

An alternative explanation for the differences in the Late Jurassic to Early Cretaceous faunas of the eastern Falkland Plateau and in southeastern Africa is presented by Jones and Plafker (this volume). They suggest that the Maurice Ewing Bank originated on the Pacific margin of Gondwanaland and subsequently drifted to its present location with respect to the western Falkland Plateau. There are, however, considerable tectonic problems associated with this explanation. Firstly, the nature and age of the basement at Site 330 indicates that it lay on the cratonic side of the late Paleozoic-early Mesozoic volcanic chain along the Pacific margin of Gondwanaland. Secondly, there is no obvious line of suture within the Falkland Plateau. Thirdly, the Maurice Ewing Bank is bordered on the north side by an escarpment that coincides rather closely with the small circle for the opening of the South Atlantic, as does the Agulhas Fracture Zone. The plateau, moreover, fits very neatly between the Mozam-

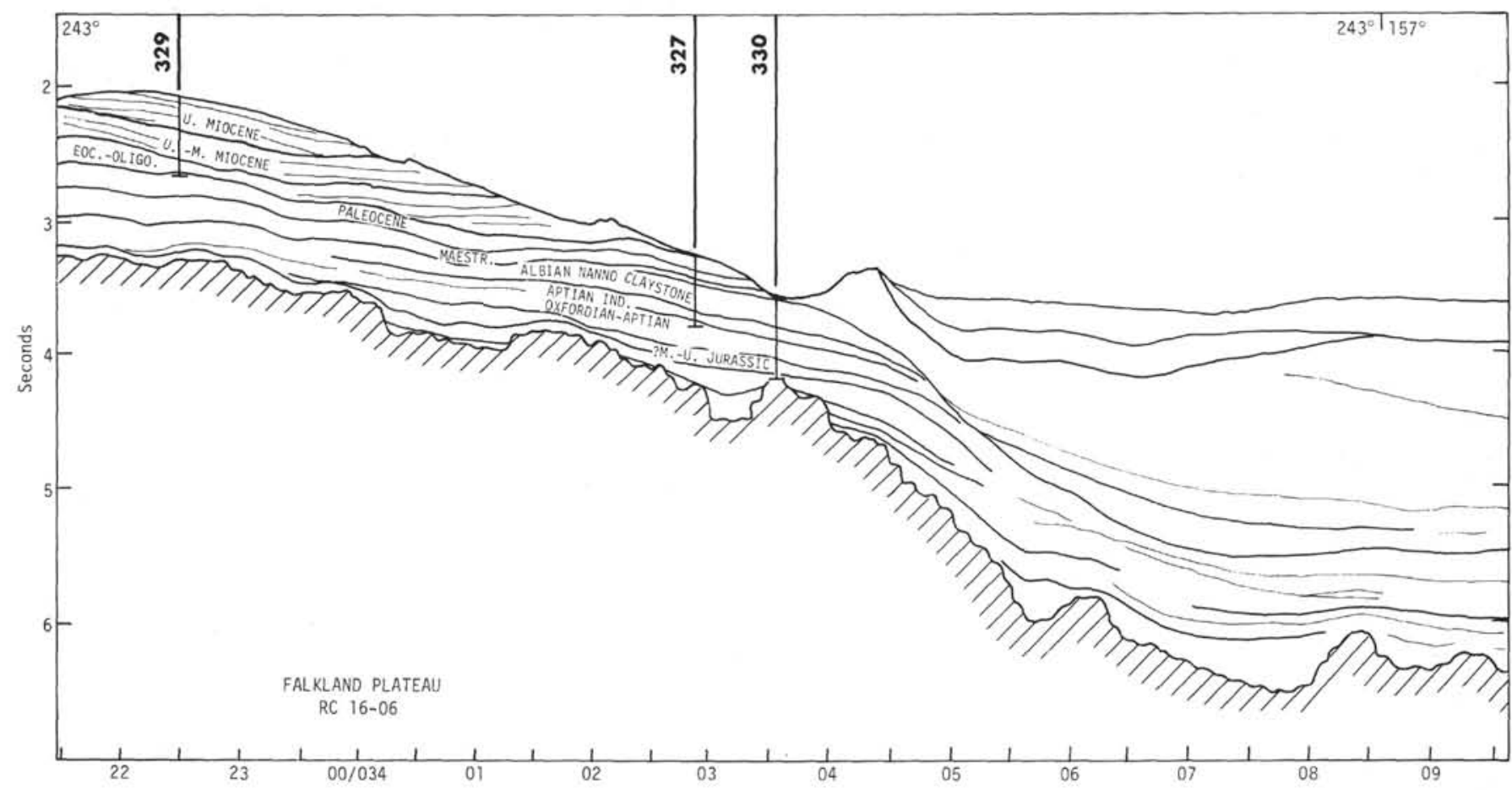

Figure 4. Interpretation of Robert D. Conrad 16-06 reflection profiler record through Leg 36 Sites 327, 329, and 330 (Barker, this volume). 
bique Rise and the southeast African continental margin.

The stagnant bottom conditions which prevailed over the Falkland Plateau during the Late Jurassic and Early Cretaceous resulted in the deposition of sapropelic sediments characterized by abundant pyrite and organic carbon concentrations that range from 0.7 to $5.1 \mathrm{wt} \%$ (Comer and Littlejohn, this volume). Sliter (this volume) estimates that deposition of the Aptian sediments occurred at shelf break depths $(100-400 \mathrm{~m})$. Similar sediments of Aptian/Barremian to Cenomanian age were cored in the North Atlantic Basin at Sites 101 and 105 on DSDP Leg 11 (Hollister, Ewing, et al., 1972); Sites 361 and 364 on Leg 40 (Bolli, Ryan, et al., 1975); and Sites 367, 368, 369, and 370 on Leg 41 (Lancelot, Seibold et al., 1975). The black shales of the Leg 11 sites have been interpreted as deep-water deposits by Lancelot et al. (1972, p. 924) who concluded that "Stagnation in the whole North American Basin, and probably in the deepest parts of the entire North Atlantic characterized most of the Early Cretaceous." The Cape Basin and the Angola Basin drilled by DSDP Leg 40 are considered by the shipboard scientists to have been stagnant during Early Cretaceous times, an observation consistent with the restricted oceanic circulation that must have existed in these basins during the early opening of the Atlantic Basin (Bolli, Ryan, et al., 1975).

Dark, organic-rich sediments of Aptian age have also been reported from open ocean sites in the west Pacific basin where geographically restricted basin conditions did not exist. Porcellanites drilled at Site 305 on the Shatsky Rise contain up to $9 \%$ organic carbon and 3\% pyrite whereas the black, carbonaceous pelagic shale penetrated at Site 310 on Hess Rise yielded abundant organic matter, pyrite, and well-crystallized rhombs of siderite, all indicative of a reducing environment (Larson, Moberly, et al., 1975). In the central Pacific, an Aptian sandstone with pyritized burrows at Site 317 on the Manihiki Plateau was found to contain as much as $30.5 \%$ organic carbon whereas sediments just above and below that stratum containes less than $1 \%$ organic carbon (Schlanger, Jackson, et al., 1976). As in the other cases, reducing conditions were inferred for the olive-black sandstone by the Leg 33 scientists.

The occurrence of organic-rich sediments of Aptian age on widely separated plateaus and rises of the central and western Pacific suggests the development of an extensive oxygen minimum layer over a large area during that time. Oxygen minimum layers can be of variable thickness depending on productivity and circulation factors, and the presumption that a well-developed layer existed at some level between 200 and 1500 meters over a large global area during Mid-Cretaceous times is not unreasonable. Where depositional surfaces along the tops or flanks of seamounts and rises were situated within such a zone, accumulation of the types of sediments described above could have occurred. Subsequent subsidence of the seamounts and rises then would explain the presence of these organic-rich sediments at depths well below those at which they were originally deposited in the oxygen minimum zone.
Because the Aptian sediments penetrated at Sites 327 and 330 on the Falkland Plateau were deposited at paleodepths estimated at between 100 and 400 meters, the presence of a well-developed oxygen minimum layer in the world's oceans during this time might account for the extensive sequence of sapropelic sediments encountered there. Organic-rich sediments in the deeper water pelagic sequences drilled to the north in the Atlantic Basin (DSDP Legs 11, 40, 41), however, cannot be explained simply by the presence of an oxygen minimum layer in the overlying near surface waters. Deep-water circulation comparable to that of today would presumably have kept the bottom oxygenated. The occurrence of bathymetric sills, though, could inhibit or prevent significant deep-water circulation and allow oxygen-deficient conditions to extend deep within the basins. This could result partly from the derivation of deep water within the basins from the oxygenminimum zone as off southern California today (Emery, 1960), and partially by the combustion of organic matter supplied to the water column of the basin by plankton production (Figure 5). The Falkland Plateau itself could have formed a sill until South Atlantic sea-floor spreading opened a gap to the east of the South American continent large enough for significant exchange of bottom waters between the growing Atlantic and Indian oceans (see next section).

A sill is also likely on the Pacific margin. By Oxfordian time a new volcanic zone was established along the Pacific margin of the South American and West Antarctic segments of Gondwanaland on top of the deeply eroded Gondwanide basement. Graben formation in a broad active rift zone, comparable to the Taupo volcanic zone of New Zealand or the Basin and Range Province of the North American Cordillera was initiated along the Pacific margin of the supercontinent (Dalziel et al., 1974b; Suarez, 1976). The volcanic zone probably resulted in the partial isolation of eastern South America from the open Pacific Ocean. Water depths in the Magallanes Basin in the Late Jurassic-Early Cretaceous were comparable to those on the eastern Falkland Plateau (Natland et al., 1974), and many of the Upper Jurassic volcanic deposits along the Pacific margin in the southern Andes are reworked in shallow water and are interlayered with sedimentary layers containing belemnites (Dalziel et al., 1974a). Hence the presence of a limited Indo-Pacific fauna on the eastern Falkland Plateau is not surprising, but open circulation with the Pacific would probably have been precluded.

\section{EARLY HISTORY OF THE SOUTH ATLANTIC: IMPROVED CIRCULATION ON THE FALKLAND PLATEAU}

The present state of knowledge of the early opening of the South Atlantic is not entirely satisfactory. Larson and Ladd (1973) identified part of the M sequence of magnetic anomalies in the Cape and Argentine Basins and assigned a date of about $127 \mathrm{~m} . \mathrm{y}$. to the initiation of sea-floor spreading. Neither this date nor the estimated $1.6 \mathrm{~cm} / \mathrm{yr}$ half spreading rate is changed significantly by more recent revision of the $\mathrm{M}$ anomaly 

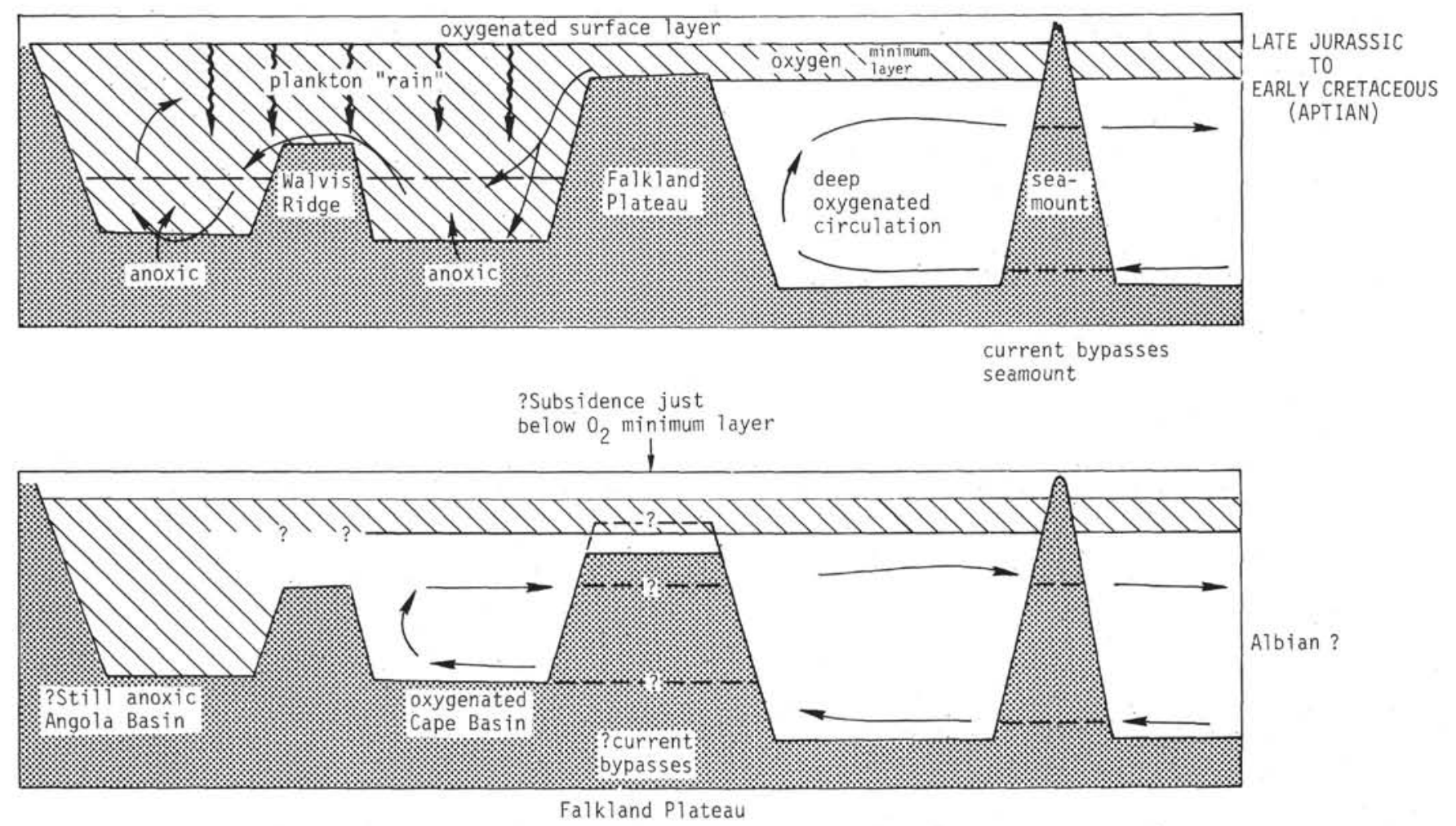

Figure 5. Diagrammatic sketches illustrating a possible cause for circulation conditions on the Falkland Plateau and in the South Atlantic basins in Late Jurassic and Early Cretaceous times. For full explanation, see text. (a.) Late Jurassic-Aptian time, organic-rich sediments on plateau developed within an oxygen minimum layer. Stagnation in the basins to the north was due to: (1.) derivation of bottom water from oxygen minimum layer; (2.) decay of plankton in the lower water coland on the bottom; (3.) restriction of bottom circulation by the Falkland Plateau. (b.)Albian time-oxygenated conditions on the plateau resulted from either sinking of the plateau beneath the oxygen minimum layer, or more likely, since there does not seem to have been a significant change in the depth of the plateau, deep circulation of oxygenated water through the developing deep seaway between the Indian and Atlantic oceans.

time scale by Larson and Hilde (1975), but the anomaly identifications have been challenged by Emery et al. (1975) who prefer a 165 m.y. initiation. Some question about the accuracy of the M anomaly time scale, and the older part of the Cenozoic and Late Cretaceous magnetic reversal time scale of Heirtzler et al (1968), arises from their combined requirement that a universal period of exceptionally fast spreading coincide with the intervening Cretaceous normal polarity interval (108 to $84 \mathrm{~m} . \mathrm{y}$.$) . There is also some uncertainty concerning$ correlation of radiometric ages with biostratigraphic and magnetic time scales for the late Mesozoic (Baldwin et al., 1974; Berggren et al., 1975; Larson and Pitman, 1972, 1975).

For Figure 6 we used the later of the two poles of Ladd (1975) and the implied rate of rotation (33.8 about $\left.63^{\circ} \mathrm{N}, 36^{\circ} \mathrm{W}\right)$ to anomaly $34(84$ m.y.). We then used his earlier pole $\left(23.4^{\circ} \mathrm{N}, 15.5^{\circ} \mathrm{W}\right)$ at a half spreading rate of $4.6 \mathrm{~cm} / \mathrm{yr}$ from anomaly 34 back to the positions shown. These positions correspond to 96 and 104 m.y., indicating that the eastern end of the plateau cleared the western margin of Africa about 100 m.y. ago (mid-Albian according to our adopted time scale; see Introduction to this volume).

Deposition of Albian-Cenomanian nanno clay at Sites 327 and 330 indicates a distinct improvement in oxygenation on the Falkland Plateau, and the start of a change to an open ocean environment which has persisted to the present day. Benthonic foraminifera within this clay (Unit 7, Site 327) imply a sea bed depth of 100 to 400 meters during the Albian. Much of the Maurice Ewing Bank and the northernmost part of the plateau to the west would have been equally shallow or shallower, and may even have been dry land (although not a significant source of sediment for Unit 7 that contains no terrigenous detritus coarser than clay). Thus, despite its continued subsidence, the plateau was probably still an effective barrier to all but surface circulation into the growing Atlantic Ocean during the Albian.

The reason for improved oxygenation was probably the establishment of a deep-water connection between the opening Atlantic and Indian oceans as the southwestern tip of the African continental margin cleared the eastern end of the Falkland Plateau (Figures $5 \mathrm{~b}$ and 6 ). This must have resulted in improved circulation and apparently a change in the depth and extent of the oxygen minimum zone as the change in depth of the plateau was small. It should be reemphasized here that the exact configuration of the other Gondwanaland continental fragments in the region during the Early Cretaceous is uncertain. Open circulation between the 


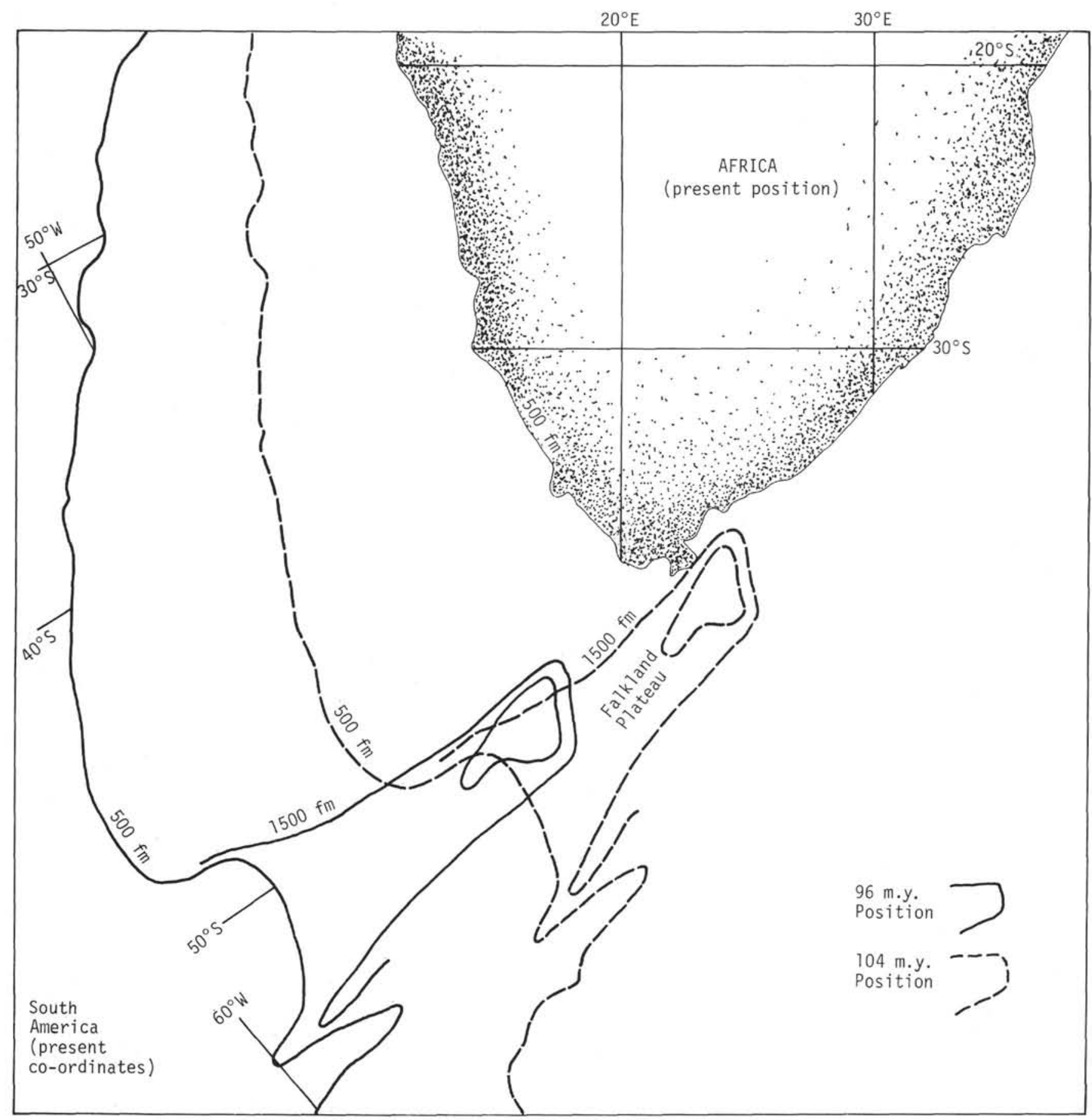

Figure 6. Positions of South America relative to Africa (fixed) at 104 m.y. and 96 m.y B.P. using the data of Ladd (1975).

plateau and the Pacific certainly of shallow waters and perhaps even of deep waters could have been possible at times. However, no permanent deep-water channel existed before Drake Passage opened between South America and the Antarctic Peninsula in the Cenozoic.

\section{MID-ATLANTIC RIDGE OFFSET AT THE \\ FALKLAND-AGULHAS FRACTURE ZONE: BASEMENT AGE AT SITE 328}

In the discussion above concerning the creation of a deep connection between the Atlantic and Indian oceans in the early to mid-Albian, we make the assumption that the crust east of the Falkland Plateau and south of the Falkland-Agulhas Fracture Zone is entirely oceanic. This is by no means obvious because seafloor spreading south of the fracture zone has been more complicated than to the north over the 127 m.y. since its inception.

We assume, from the close fit of the Falkland Plateau to the southeast margin of Africa (Figures 3 and 6) and from other considerations discussed above, that the plateau has remained rigidly attached to South 
America at least since the earliest Cretaceous when the South Atlantic started to open. We make the same assumption about the relation between the Mozambique Ridge and Africa though with little direct supporting evidence. Thus, the initial offset of the midAtlantic spreading center across the Falkland-Agulhas Fracture Zone must have been at least $1400 \mathrm{~km}$, the present length of the northern margin of the Falkland Plateau. The present offset, as delineated by earthquake epicenters (Barazangi and Dorman, 1969) and magnetic anomalies (Ladd et al., 1973) is about $250 \mathrm{~km}$, only one-sixth the distance. The remainder of the former offset has been eliminated over the past $127 \mathrm{~m} . \mathrm{y}$. by relative westward movement of the more southerly section of ridge crest, either by sustained asymmetric spreading or, more likely, by one or more "jumps" in position. Once the possibility of jumps in the position of the spreading center is admitted, it is clear that the present eastern margin of the Falkland Plateau need not have formed the original break with Africa as was assumed in the previous section. A fragment of continental crust could have been detached from the extremity of the plateau subsequent to the initial continental separation. The timing of the ridge jump or jumps is constrained by the available bathymetric and magnetic data in the South Atlantic Ocean basin, and by what can be inferred of the basement age at Site 328, which lies south of the Falkland Fracture Zone and 240 $\mathrm{km}$ east of the Falkland Plateau.

Published magnetic profiles from the South Atlantic (Ladd et al., 1973) show the areas to either side of the Falkland-Agulhas Fracture Zone, but only out to anomaly 21 (53 m.y.) south of the fracture zone. The profiles show that the offset at $53 \mathrm{~m} . \mathrm{y}$. was the same as the present distance, and that spreading to the south was as symmetric as that to the north. Thus $1150 \mathrm{~km}$ of offset was eliminated before 53 m.y. At Site 328, sediments 130 meters above acoustic basement are of Santonian to late Turonian age. If observed sedimentation rates are extrapolated, acoustic basement would be of early Turonian to late Aptian age. Such extrapolation back at least to the Cenomanian is justified if the explanation below concerning high rates of sedimentation of pelagic clay at Site 328 is correct. These are considered to be minimum ages for formation of ocean crust at Site 328 since acoustic basement may lie above the basaltic layer. If we do assume a $127-\mathrm{m} . \mathrm{y}$. start of spreading, a half rate of $1.6 \mathrm{~cm} / \mathrm{yr}$ from then to 108 m.y. (Larson and Ladd, 1973; Larson and Hilde, 1975) and a $4.6 \mathrm{~cm} / \mathrm{yr}$ half rate from 108 to 84 m.y., both about a pole at $23.4^{\circ} \mathrm{N}, 15.5^{\circ} \mathrm{W}$ (Ladd, 1975 ), we can estimate the basement age at Site 328 under various hypotheses.

The first and simplest hypothesis is that the ocean crust between the eastern margin of the plateau and Site 328 was formed during the initial stages of the separation and was not disturbed by any subsequent jump. In this case the jump or jumps took place entirely to the east. The age of the crust $240 \mathrm{~km}$ east of the plateau would then be 112 m.y., early Aptian, consistent with findings at Site 328 provided that initial sedimentation rates there were somewhat lower than those recorded between the Late Cretaceous and the late Eocene. For this stretch of ocean crust to have remained undisturbed by a later single jump, at least $1150 \mathrm{~km}$ of crust would have had to form to the east before the jump. Thus, under this hypothesis, a single jump could not have taken place before about $84 \mathrm{~m} . \mathrm{y}$. ago. This hypothesis, tenable on present evidence, is illustrated in Figure 7a. A possible modification would be that any number of smaller jumps, aggregating $1150 \mathrm{~km}$, may have taken place, provided the first did not occur before $112 \mathrm{~m} . \mathrm{y}$. and the last not before $84 \mathrm{~m} . \mathrm{y}$. or after 53 m.y., in order to preserve the ocean floor between the plateau and Site 328 .

The simplest version of the alternative hypothesis, that the present eastern margin of the Falkland Plateau postdates elimination of the entire ridge offset, is illustrated in Figure 7b. Under this hypothesis, the margin would be 90 m.y. old, and Site 328 would be 85 m.y. old, or earliest Santonian. This can be reconciled only by assumption of an improbable paleontologic age for the oldest sediments cored and a very high earlier sedimentation rate. Data from Site 328 therefore argue against the hypothesis in such a simple form. If, however, we assume that not all of the offset was eliminated by this main early jump, the hypothesis can be reconciled with the data. For example, Scrutton (1973) proposed that a jump in the spreading center to the eastern end of the Falkland Plateau took place from the center of the Agulhas Plateau, as shown
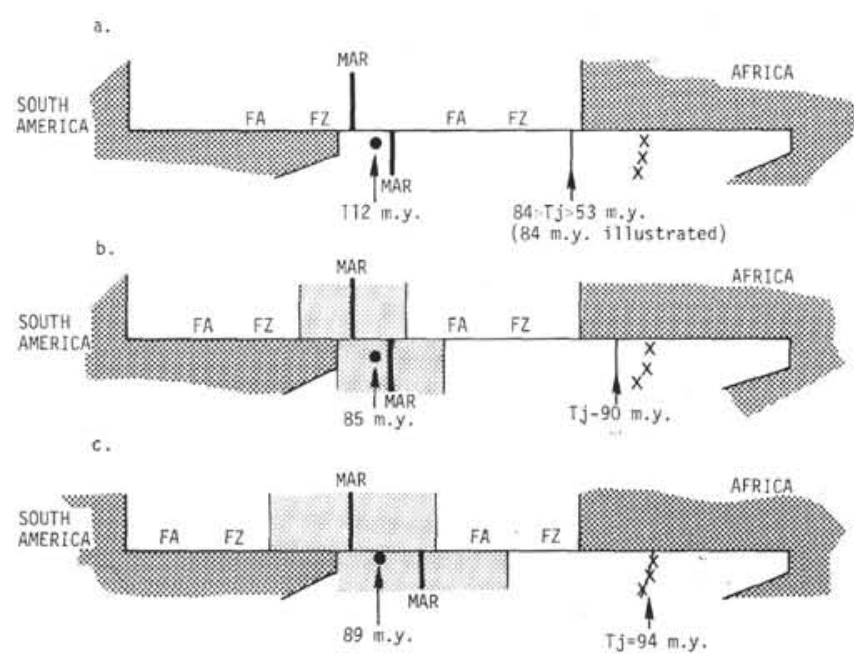

a. Site 328 on pre-jump ocean crust.

. Site 328 on post-jump ocean crust.
Angulhas plateau as abandoned ridge crest.

Continent (? and pre-127 m.y. old ocean crust).

Old (pre-jump) ocean crust, with position

of abandoned ridge crest.

New (post-jump) ocean crust.

- Site 328

$X$ Agulhas Plateau

MAR Mid-Atiantic Ridge

FAFZ Falkland-Agulhas
Fracture Zone

Figure 7. Models for the evolution of the offset in the crest of the Mid-Atlantic Ridge across the Falkland-Agulhas Fracture Zone (FAFZ); for explanation see text. 
schematically in Figure 7c. There is much supporting evidence for the proposal that the Agulhas Plateau has an oceanic crustal structure despite its anomalous elevation; that it is an abandoned ridge crest is more conjectural. We estimate, however, that only $950 \mathrm{~km}$ of the offset would have been eliminated by such a jump, given symmetric spreading, thus leaving another 200 $\mathrm{km}$ to be eliminated by a later jump or jumps, not affecting the Falkland Plateau directly. Under the previous assumptions, the main jump would have occurred at about 94 m.y., marginally consistent with the presence of Cenomanian sediments on the Agulhas Plateau. The age of ocean floor at Site 328 would be 89 m.y., or Turonian. Thus, our data do not contradict Scrutton's proposal; however, the fact remains that not all of the offset is eliminated.

Virtually all valid hypotheses for elimination of the offset have as a corollary the existence of deep water directly east of the Falkland Plateau at the time when its eastern end cleared the southwestern corner of the African margin. Indeed, in all but the most complicated options, the particular area of deep ocean floor in question now lies exactly where it lay then, either with respect to the Falkland Plateau, or with respect to the southwest corner of the African margin. Both of these areas appear to be at normal oceanic depths.

Thus, in summary, we can rule out the hypothesis that all of the difference between the original and present offset of the Mid-Atlantic Ridge crest was eliminated by a single jump of the crest to the eastern margin of the Falkland Plateau. This would require the ocean crust at Site 328 to be too young. Most other options of a jump or jumps before $53 \mathrm{~m} . \mathrm{y}$. to a position east of Site 328, or of a jump before about 89 m.y. to west of Site 328, which would not eliminate all of the offset, are possible. Additional magnetic data are required to resolve the problem because the existing data (including Leg 36 underway data, Barker, this volume) are inadequate.

\section{LATE MESOZOIC-LATE EOCENE SEDIMENTATION IN THE MALVINAS OUTER BASIN}

From the Late Cretaceous to the late Eocene relatively fast deposition of clays occurred in the Malvinas Outer Basin. These sediments accumulated below the carbonate compensation depth (CCD) in an environment effectively isolated from coarse-grained terrigenous detritus and, for most of the time, sufficiently quiescent to allow the settling of fine clays. The average sedimentation rate of about $10 \mathrm{~m} / \mathrm{m} . \mathrm{y}$. for this interval is abnormally high (roughly by an order of magnitude) for clays in the deep ocean basins remote from a continental rise. Therefore, an unusual supply of argillaceous material and efficient trapping of fine sediment in the partially enclosed Malvinas Outer Basin is indicated.

The most probable source for the argillaceous material is the Andean Cordillera, and possibly the West Antarctic Cordillera with which it was certainly joined in some fashion (Dalziel and Elliot, 1971, 1973; Barker and Griffiths, 1972; Suarez, 1976). The Mal- vinas Outer Basin lies south of the Falkland Fracture Zone, west of the Mid-Atlantic Ridge, and north of the north Scotia Ridge (Figure 1). Between the Falkland Plateau and the north Scotia Ridge lies the deep and sediment-filled Falkland Trough which shallows westward toward the continental margin of South America (Figure 8). A pronounced gravity low (Davey, 1972; unpublished data of Lamont-Doherty Geological Observatory and the University of Birmingham) parallels the trough, being situated along the deepest part of the sedimentary infill directly south of its bathymetric axis (Ewing et al., 1971; Davey, 1972). At the western end the gravity minimum appears to be continuous with the late Mesozoic-Cenozoic Magallanes Basin which bounds the southernmost part of the Andean Cordillera on its Atlantic side (Natland et al., 1974; see Figure 8). The "basement" contours shown in Figure 8, taking basement to be material with P-wave velocities of $4.5 \mathrm{~km} / \mathrm{sec}$ or greater, do not show the Magallanes Basin and the Falkland Trough to be physiographically continuous (Ludwig et al., 1968). However the gravity data indicate that although a deep basement "sill" may separate the two basins, the Magallanes Basin and the Falkland Trough probably have the same sedimentary infilling.

The main deformation and initial uplift of the southern part of the Andean Cordillera took place in the late Albian-Cenomanian (Dalziel, 1974; Dalziel and Palmer, in press). At this time there was a marked increase in the depth of the Magallanes Basin from less than 500 meters to greater than 1500 meters (Natland et al., 1974, table 1). Sediment was supplied down an eastward-dipping slope from the Cordillera, as evidenced by slump folds and the provenance of Upper Cretaceous flysch deposits in the basin, and was transported southwards along the basin axis parallel to the Cordillera (Scott, 1966). North of $50^{\circ} \mathrm{S}$ the basin shallows (Figure 8), and the Upper Cretaceous sediments undergo a facies change from marine to subaerial. Thus it can be demonstrated that a part of the present Andean Cordillera was a feasible source for the Upper Cretaceous to upper Eocene clays in the Malvinas Outer Basin. However, this Cordilleran source probably continued, prior to breakup of the North Scotia Ridge, even farther east along the southern margin of Burdwood Bank (Dalziel et al., 1975 c). This may have shed sediment directly north into the Falkland Trough.

The material being eroded from the rising Cordillera in the Late Cretaceous included silicic, intermediate, and mafic igneous rocks and volcaniclastic sedimentary rocks. Hence the Cordillera constituted a suitable source for the clays and claystones of the Malvinas Outer Basin which are rich in montmorillonite, have a high amorphous content, and commonly contain zeolite. Trace elements show the variation of provenance with time which is to be expected (Tarney and Donnellan, this volume).

Alternative possibilities are that the sediment was derived from the West Antarctic Cordillera or from an African source. Volcaniclastic flysch of Cretaceous age is known in the southern Antarctic Peninsula (Suarez, 1976), but the way in which the sediment would have 


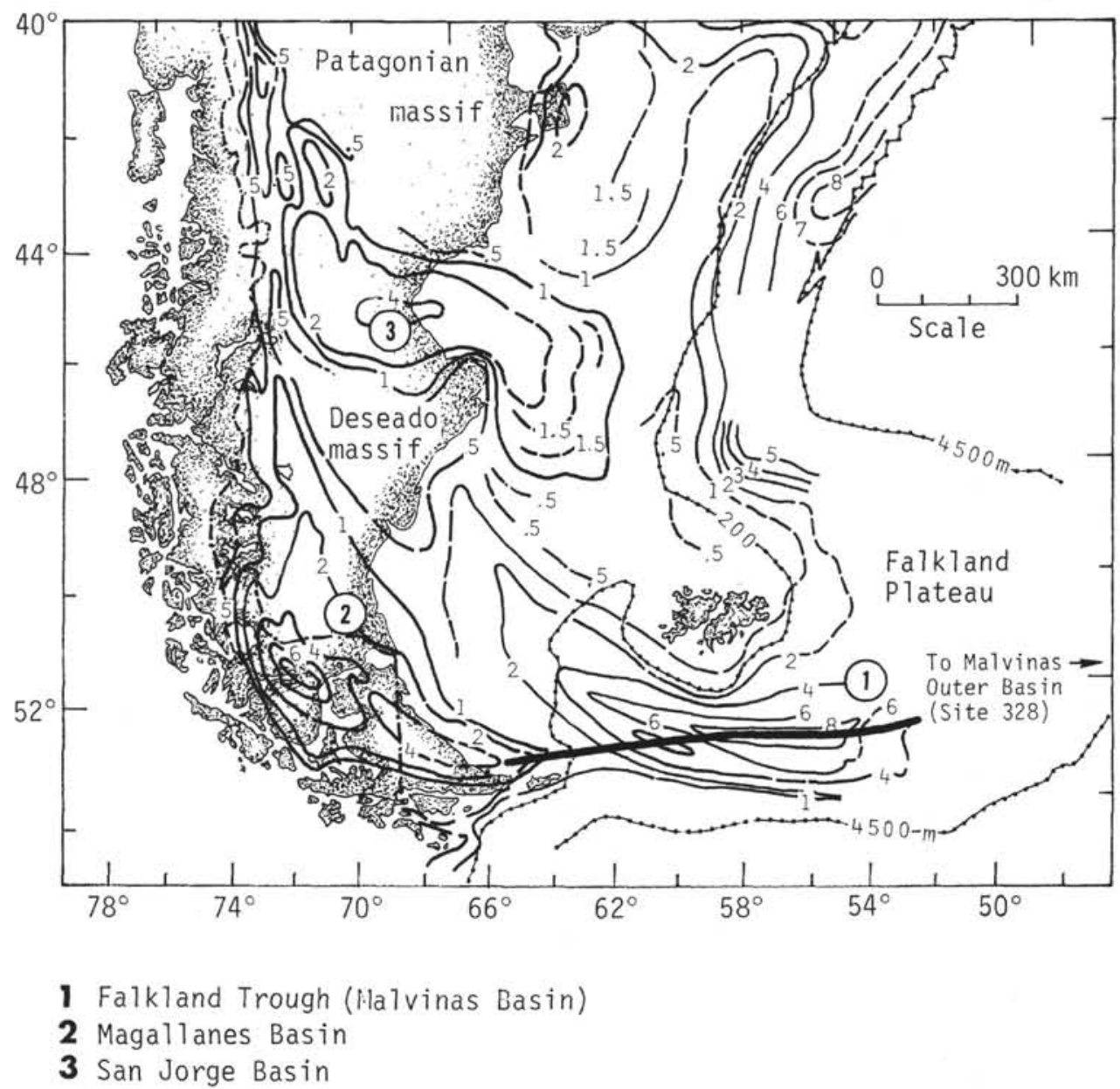

Figure 8. Relation between the Falkland Trough and the Megallanes Basin. Isopachs represent kilometers of late Mesozoic and Cenozoic sedimentary cover on top of MiddleUpper Jurassic volcanic or Paleozoic-early Mesozoic metamorphic-plutonic basement (after Urien and Zambrano, 1973). Axis of gravity minimum from unpublished data of the University of Birmingham.

been transported to the Malvinas Outer Basin is unclear. An African source for the sediment cannot be ruled out but appears unlikely. The Falkland-Agulhas Fracture Zone forms an efficient sedimentary barrier (Le Pichon et al., 1971; Dingle and Scrutton, 1974), and the clays of the Jurassic sediments derived from the African-Falkland Plateau basement at Site 330 are dominantly illite while the clays and claystones of the Malvinas Outer Basin are rich in montmorillonite.

The steady deposition of fine clays took place at Site 328 during the Late Cretaceous and until the late Eocene, except for an apparent 5-10 m.y. hiatus at the Cretaceous-Tertiary boundary. This hiatus is known mainly as a gap in carbonate sedimentation, but it has been observed elsewhere as an event of either nondeposition or very slow accumulation of pelagic clays over a variable period of time (Hayes, Frakes, et al., 1975; Perch-Nielsen, Supko, et al., 1975; Luyendyk and Davies, 1974; Bolli, Ryan, et al., 1975; Lancelot, Seibold, et al., 1975; Tucholke, Vogt, et al., 1975). We cannot at present suggest a specific reason for this short-lived but significant event. Most likely, however, it involves a global rather than a local phenomenon. At Site 328 the hiatus coincides approximately with the faint and diffuse seismic reflector correlated by Ewing and Lonardi (1971) with the somewhat more distinct Horizon A of the Argentine Basin. Physically, however, the reflector at Site 328 originates in an increase in compaction and diagenesis down the hole (as elsewhere in the South Atlantic Ocean basin) and therefore may not be correlative with the hiatus.

The bottom current regime which prevailed for most of the Late Cretaceous and early Paleogene in the Malvinas Outer Basin is unknown. In the late Eocene or early Oligocene at Site 328, rapid deposition of clays changed after a short hiatus to much slower deposition of siliceous ooze. As in the case of the CretaceousTertiary boundary hiatus, the reasons for this change are probably related to circulation and will be discussed in detail below. In addition, however, the supply of sediment from the Andean Cordillera may have slowed down as sedimentation on the Atlantic side of the Cordillera gradually changed from flysch-type to mollassetype facies (Scott, 1966). 


\section{LATE CRETACEOUS AND PALEOGENE SEDIMENTATION ON THE FALKLAND PLATEAU}

From Albian times onwards the depositional environment on the Maurice Ewing Bank was characterized by open ocean conditions. With no signs of restriction and with a virtual absence of even silt-sized terrigenous detritus, an interplay of bottom currents, CCD migration, and siliceous productivity governed deposition. Benthonic foraminiferal assemblages (Sliter, this volume) suggest sea bed depths at Site 327 of 100 to 400 meters in the Albian, 3000 to 4000 meters in the Santonian, and 1500 to 2000 meters in the Campanian-Maestrichtian. Discounting the Santonian depths, which will be discussed below, the data fit a simple curve of oceanic thermal subsidence (Figure 9) with a time constant of 30 m.y. (Parker and Oldenberg, 1973), starting at 100 meters in the Albian and ending at the present depth. This would be appropriate to a small continental body essentially surrounded by oceanic crust and not involved in any significant tectonic events during the period concerned. Kinsman (1975) has shown that even a normal rifted continental margin will subside in much the same way as oceanic crust with time.

Sedimentation conditions during the Late Cretaceous to early Tertiary were quite variable; calcareous oozes, claystones, or chalks are found in the Albian, early Cenomanian, late Campanian, Maestrichtian, Paleocene, Eocene, and Oligocene; zeolitic or siliceous clays and oozes without calcareous remains accumulated in the Santonian and Paleocene. The intermittent presence of calcareous microfossils possibly results from CCD variations. Hiatuses are common in this part of the section. Some may be of purely local significance, reflecting only the specific location of the plateau within the surrounding ocean, but others, such as the hiatus at the Cretaceous-Tertiary boundary, are known worldwide. Perhaps the most noteworthy hiatus is the condensed section at Site 327 where only 12 meters of sediment accumulated in $15 \mathrm{~m} . \mathrm{y}$. between deposition of an early Cenomanian nanno clay and a late Campanian nanno ooze. Santonian zeolitic clay sampled from this interval yielded only sparse, dissolution-resistant calcareous nannoflora and rare abyssal, cold-water benthonic foraminifera, the latter indicating either an anomalously great water depth (Figure 9) or else very cold water being carried to unusually shallow depths. As there is no other evidence that the Falkland Plateau descended to $3000-4000$ meters in the Mid-Cretaceous and "rebounded" to 1500-2000 meters by the end of the Cretaceous, an explanation involving circulation changes is more attractive.

The significance of the condensed section is difficult to assess. Veevers and Heirtzler (1974) report a depositional hiatus extending over the Turonian and Coniacian at DSDP sites on the western margin of Australia, and they attribute this to circulation changes caused by establishment of a shallow marine connection between the Pacific and Indian oceans along the line of subsequent separation of Australia from Antarctica. A similar mechanism, involving perhaps an enhanced meridional flow of water over a subsiding Falkland Plateau, may have prevented deposition throughout the Turonian and Coniacian. Reflection profiles show no evidence of large amounts of erosion during this period; however, subsequent deposition appears to have been under conditions of steadily increasing bottom current velocity. Also, all models, including any which involve particularly strong currents flowing around the eastern Falkland Plateau during the Late Cretaceous, must allow also the steady deposition of fine clays at Site 328 and be compatible with their likely transport eastward by bottom currents along the ancestral Falkland Trough, directly south of the plateau.

Deduction of the current regime over the Falkland Plateau is important for estimating the nature of the great thickness of sediments occupying the basin province of the plateau (Figure 4), which was not sampled by Leg 36 holes. Essentially, the reflection profile shows that the contrast in the basement between shelf and basin is preserved by the overlying sediments, which build out the shelf until the Albian, when the sedimentary regime changes. The Aptian-Albian boundary in the basin probably lies at between 5.2 and $5.5 \mathrm{sec}$. The two strong reflectors at about $4 \mathrm{sec}$ are probably Neogene submarine erosion surfaces, so that at least $1.2 \mathrm{sec}$ and probably more than $1.5 \mathrm{sec}$ (up to 2 $\mathrm{km})$ were deposited in the Late Cretaceous and Paleogene (Barker, this volume).

\section{POST-EOCENE SEDIMENTATION: CLIMATIC DETERIORATION, ANTARCTIC GLACIATION, AND THE CIRCUMPOLAR CURRENT}

\section{Maurice Ewing Bank}

The major influences on post-Eocene sedimentation on the Maurice Ewing Bank were increased bottom currents and higher productivity. At Site 329 thick middle and late Miocene calcareous and siliceous ooze overlies much thinner and more slowly deposited Oligocene, Eocene, and Paleocene ooze and chalk. A probable hiatus extending over the early Miocene and an unknown amount of the Oligocene is seen in the reflection profiles to be a more general unconformity. A further hiatus extends over an unknown amount of the Eocene and early Oligocene. Post-Eocene microfossils all indicate cool to cold water temperatures, in contrast with the apparently milder climate of the Paleocene and early Eocene.

Sites 327 and 330 on the bank are of little interest here, having either no, or very little, significant postEocene sediment. What there is was probably reworked, and is in any case very poorly sampled. Figure 5 shows the relationship of these two sites to the more useful Site 329, which lies at the apex of a bank of Neogene ooze that does not extend as far downslope as Sites 327 and 330.

At present a regime of nondeposition or erosion probably exists over the entire eastern Falkland Plateau under the influence of very strong bottom currents 


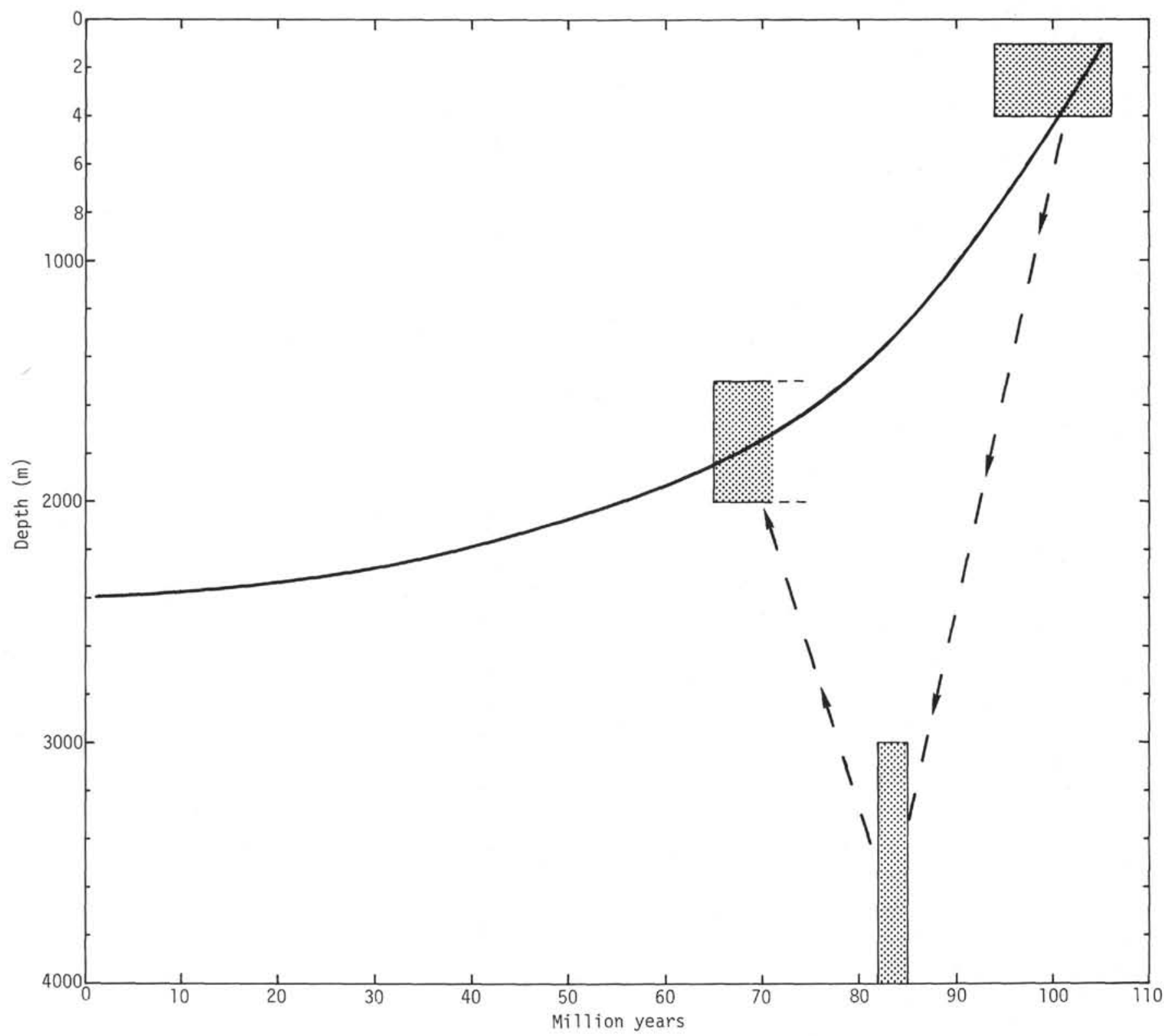

Figure 9. Depth versus age curve for Falkland Plateau sites by analogy with oceanic crust from Parker and Oldenburg (1973). Paleontologic depth estimates for the Falkland Plateau are from Sliter (this volume).

emerging from the funnel of Drake Passage (Figure 10a). This regime has existed since at least the late Miocene and probably earlier, since Miocene sediments are thick, yet so restricted in areal extent. Over the southeastern part of the plateau, it is possible that erosion may be prevented or slowed significantly at present, despite strong bottom currents, because of the protection afforded by the coarser ice-rafted debris.

\section{Malvinas Outer Basin}

Rapid deposition of Late Cretaceous and early Paleogene clay at Site 328 in the Malvinas Outer Basin gave way to more slowly deposited siliceous ooze after a late Eocene to early Oligocene hiatus. Further hiatuses span the early Miocene and early Pliocene. The earliest ice-rafted debris is late Miocene (see Plafker et al., this volume). The only post-Miocene sediment at
Site 328 is 4.5 meters of Plio-Pleistocene diatomaceous ooze with abundant ice-rafted material.

The reduced rate of sedimentation at Site 328 since the Eocene suggests that the fine clays were being transported elsewhere due to increased bottom currents. However, these low rates are not representative of the whole basin. To the southwest, at the mouth of the Falkland Trough, the ooze layer which is 50 meters thick at Site 328 exceeds $1.5 \mathrm{~km}$ (University of Birmingham unpublished reflection profiles), indicating the very high average sedimentation rate of 40 $\mathrm{m} / \mathrm{m}$.y. since the Eocene. Within this sediment pile may be an admixture of reworked terrigenous and pelagic debris from Burdwood Bank and the Falkland Plateau. However, it seems reasonable that the greater part should be primary biogenic ooze, as its acoustic character suggests. The Antarctic Circumpolar Current at 
present is too fast over a considerable distance to the west of the plateau to permit deposition of such material in the zone of high siliceous productivity south of the Antarctic Convergence. Much of the biogenic material may therefore be carried by the Circumpolar Current northeastward into the Falkland Trough and deposited where the current slackens.

It is well established that, at the present time, Antarctic Bottom Water flows northward through the Malvinas Outer Basin, past Site 328 and through a gap at $36^{\circ} \mathrm{W}$ in the Falkland Fracture Zone, into the Argentine Basin (Figure 10a). In the Argentine Basin the flow constitutes a deep western boundary countercurrent which transports clays as a nepheloid layer, winnows continental margin turbidites, and is thought to have eroded much of the older continental rise sediment at the margin (Le Pichon et al., 1971; Ewing and Lonardi, 1971). Clearly the present current regime is substantially different from the one which allowed deposition of clays at Site 328 before the late Eocene.

\section{Drake Passage Opening}

The present extremely vigorous circulation of water at all levels across the Falkland Plateau leads us to suspect the overwhelming importance of the Antarctic Circumpolar Current in controlling sedimentation for as long as it has been in existence. Equally, the generally quiet conditions observed at Leg 36 sites until the Eocene argue against the earlier existence of a deepwater channel through which such a current could flow from the Pacific.

The history of opening of Drake Passage is not established with certainty. A northeast-southwest orientation of oceanic magnetic lineations in Drake Passage, parallel to a centrally situated double bathymetric ridge, indicates a northwest-southeast separation of the south Scotia Ridge from southern South America (Barker, 1970), but the magnetic anomalies have not been dated conclusively. Attempts during Leg 36 to supplement the magnetic data with two paleontologic dates from the floor of Drake Passage failed. The most useful information at present is a 20 to $30 \mathrm{~m} . y$. age for the initial opening derived from the generalized water depth at the northern margin (Barker, in press). Thus a crude but reasonable correspondence exists between the estimated time of opening of Drake Passage and the late Oligocene-early Miocene hiatuses at Sites 329 on the Falkland Plateau and 328 in the Malvinas Outer Basin. Certainly the Late Cretaceous-Paleocene and late Eocene-early Oligocene hiatuses in the Malvinas Outer Basin appear to precede Drake Passage opening. Apparent absence of Oligocene sediments at Sites 322 and 323 in the Bellingshausen Abyssal Plain to the west of Drake Passage (Fred Weaver, personal communication, 1976) may also indicate strong bottom activity that could be attributed to Drake Passage opening (Craddock and Hollister, in press).

There are other consequences of Drake Passage opening. The continental fragments which now make up the North and South Scotia Ridge are considered to have formed a continuous Pacific margin between South America and the Antarctic Peninsula before this opening (Hawkes, 1962; Dalziel and Elliot, 1971, 1973; Barker and Griffiths, 1972). Thus the South Scotia Ridge, which controls the northward movement of Weddell Sea Bottom Water, and the North Scotia Ridge, which controls similarly the northeastward flow of the Circumpolar Current, probably have attained their present positions only since the initial opening; indeed, some parts may still be moving (Forsyth, 1975). Also, the volcanic arc of the South Sandwich Islands is presently moving rapidly eastward relative to the central part of the Scotia Sea (Barker, 1972), and only 8 m.y. ago was no farther east than the present position of South Georgia. Without knowing exactly the movements of each block, we can draw the general conclusions that: (a) at the time of initial opening the northward flow of cold bottom water from the Weddell Sea would have been less impeded than at present, (b) the early Antarctic Circumpolar Current would probably have been more impeded (by a denser concentration of continental fragments) and, (c) the tectonic evolution of the Scotia Sea since the initial opening is likely to have caused second-order changes in current flow over the entire Falkland Plateau and in the Malvinas Outer Basin. To what extent these factors were responsible for the changes in sedimentation observed on the plateau, such as the restricted bank of middle and late Miocene ooze, and the erosion and later infilling downslope from Site 330, is not known; however, any attempt at a detailed paleoclimatic interpretation of these changes must take the tectonic events into consideration.

\section{CENOZOIC OCEANIC CIRCULATION AT HIGH SOUTHERN LATITUDES: A DISCUSSION}

In a region of tectonic complexity such as the southwestern Atlantic, distinction between the effects of local and global events is often difficult. In this section we consider sedimentation during the Cenozoic on the Maurice Ewing Bank and in the Malvinas Outer Basin in light of the evidence from throughout the Southern Ocean that bears on the history of Antarctic glaciation and the Antarctic Circumpolar Current. We consider whether the Pacific margin of southern South America and the Antarctic Peninsula was in fact the last barrier to complete circum-Antarctic circulation, since it is by no means obvious that fast bottom currents with the velocity observed today would result from the creation of an incomplete circumpolar path.

Deep Sea Drilling Project sites in all sectors of the Southern Ocean reveal certain similarities in their Cenozoic geologic histories. A hiatus near the EoceneOligocene boundary is common at deep water sites; another near the Oligocene-Miocene boundary has been widely reported. Circulation generally becomes more vigorous throughout the Cenozoic and at many sites the Neogene record is fragmentary. A general cooling trend started in the late Eocene, leading to the present Antarctic glaciation. The effects of the Antarctic Circumpolar Current and of cold corrosive bottom waters are widely observed.

The widespread nature of an Oligocene hiatus within the Indian Ocean was demonstrated by Luyendyk and 
Davies (1974) on the basis of the results of Legs 22-27. Although they were considering only sites north of $40^{\circ} \mathrm{S}$ latitude, they showed that the duration of the hiatus increases southwards. It is also longer in the western Indian Ocean than in the east and in a few sites extends from the late Eocene until the early Miocene. Although at the time Luyendyk and Davies referred to the hiatus as either an erosional unconformity or a "carbonate gap," the data do suggest that more vigorous circulation, presumably a western boundary undercurrent, may have been responsible. The subsequent Legs 28 and 29 in the area south and southeast of Australia were able to distinguish two discrete erosional events near the Eocene-Oligocene and the Oligocene-Miocene boundaries.

At Site 283 in the Tasman Sea a late Eocene to late Miocene hiatus was followed by slow accumulation of zeolitic clay. This site is compared by Kennett, Houtz, et al. (1975) to the Leg 21 sites in the Coral Sea (Burns, Andrews, et al., 1973) which show a widespread late Eocene-early Oligocene hiatus. Combining this information with the distinct cooling observed in both surface and bottom waters towards the close of the Eocene (Savin et al., 1975; Shackleton and Kennett, 1975), Kennett, Houtz, et al. (1975) infer the inception of a strong, cold, western boundary undercurrent at that time in the Tasman and Coral seas as part of an invigorated thermohaline circulation. They speculate that Antarctic glaciation had by then developed sufficiently to allow the formation of bottom water in the Ross Sea by the same process as occurs today.

While there is now general agreement that glaciation of the Antarctic continent became well established during the Miocene (Denton et al., 1971; Frakes and Kemp, 1972; Kennett et al., 1975), the extent of the ice prior to that epoch is still uncertain (Drewry, 1975). On Leg 28 the earliest ice-rafted debris was found in upper Oligocene sediments at Ross Sea sites (25 m.y.; Allis et al., 1975) and in Miocene and younger sediments at more northerly deep-water sites (Kemp et al., 1975). Evidence obtained during Leg 35 in the Bellingshausen Sea off the base of the Antarctic Peninsula indicates the presence of weak glaciation in the early Miocene and a fully established ice sheet by the late Miocene (Craddock, Hollister, et al., in press). However, neither Eocene nor Oligocene sediments were recovered during the Leg 35 drilling program. No direct evidence bearing on the presence, or size, of an ice sheet on the Antarctic continent during the Oligocene or earlier was obtained during Leg 36. Nevertheless we must emphasize the similarities between the conditions found to have prevailed in the Tasman and Coral seas from the late Eocene into the Oligocene, and those at Site 328 in the Malvinas Outer Basin. The late Eocene to early Oligocene hiatus there, together with the sharp drop in sedimentation rate, strongly advocate the inception of a western boundary undercurrent in the South Atlantic Ocean Basin at that time. Presumably the current originated in the Weddell Sea as it does at the present time (Figure 10b).

Whatever the stage reached by Antarctic glaciation in late Eocene-early Oligocene time when corrosive bot- tom currents became an important agent in deep-sea sediment transport in the southwestern Pacific and southwestern Atlantic Ocean basins, it is clear that bottom currents existed before Australia and South America separated from Antarctica. A complete Antarctic Circumpolar Current, however, could not develop until open seaways were developed to the south of Australia and South America. The separation of Antarctica and Australia started 55 m.y. ago, but the continental South Tasman Rise impeded deep circulation in the early stages of separation. Hayes and Frakes (1975) note that a deep channel was opening in the early Oligocene. However, the strike-slip relative motion between the rise and East Antarctica make the exact timing uncertain (Weissel and Hayes, 1972).

Estimates of the time of inception of a Circumpolar Current have varied from late Eocene (36-41 m.y.) based on Australian echinoids (Foster, 1974), to late Oligocene (27-28 m.y.) based on planktonic foraminifera from the Southwest Pacific Ocean. Kennett et al. (1975) suggest that it was the inception of the Circumpolar Current which in the late Oligocene ( $\sim 30$ m.y.) forced the western boundary undercurrent eastward from an original path directly east of Antarctica, to head instead northward along the eastern margin of New Zealand, as it does today. However, evidence of erosion on the eastern Falkland Plateau as well as in the deep Malvinas Outer Basin during the early Miocene, might indicate that development of a complete Circumpolar Current awaited the opening of Drake Passage in the early Miocene.

\section{NOTE ADDED IN PROOF \\ (P.F. Barker and J. Burrell)}

The history of opening of Drake Passage is central to an understanding of Cenozoic sedimentation at Leg 36 sites. Drilling at Site 326 failed to provide an age of oceanic basement which in combination with existing magnetic anomaly data would have contributed to a direct solution of this problem, and sedimentation on the Falkland Plateau was apparently subject to other influences which made an indirect determination less than certain.

Additional magnetic profiles obtained aboard RRS Shackleton in early 1976 have now yielded a virtually complete history of opening (Barker and Burrell, unpublished). Drake Passage formed by the separation of the south Scotia Ridge from South America along about $125^{\circ}$. Initial opening was relatively fast $(>20 \mathrm{~mm}$ per year from about 29 m.y.) but slowed later and probably has now stopped. The existence of fracture zone ridges along the Shackleton Fracture Zone could have restricted deep circulation (below $2000 \mathrm{~m}$ ) in the early stages of opening. A narrow, shallow gap (less than 50 $\mathrm{km}$ wide and $1000 \mathrm{~m}$ deep) probably existed for some time before 29 m.y.

\section{REFERENCES}

Allis, R.G., Barrett, P.J., and Cristoffel, D.A., 1975. A paleomagnetic stratigraphy for Oligocene and early Miocene marine glacial sediments at Site 270, Ross Sea, 


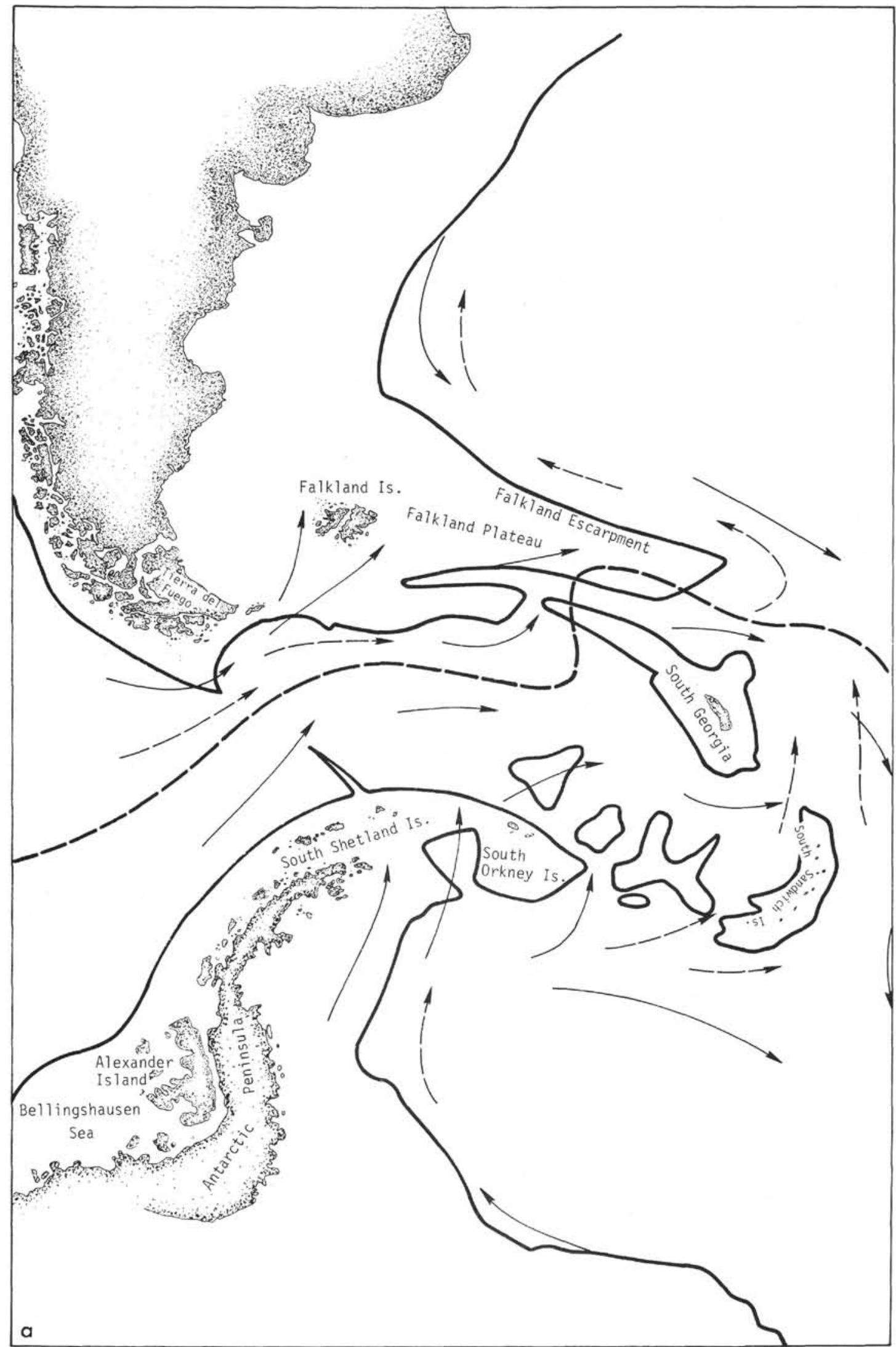

Figure 10. Suggested present (a) and Oligocene (b) current regime for the Drake Passage and southwestern Atlantic Ocean basin. Present regime based on data from Gordon (1971), Le Pichon et al. (1971), and Goodell (1973). Oligocene regime based partly on work by Gill and Bryan (1971) and Kennett, Houtz, et al. (1974). Solid arrows show shallow currents, dashed arrows deep currents. 


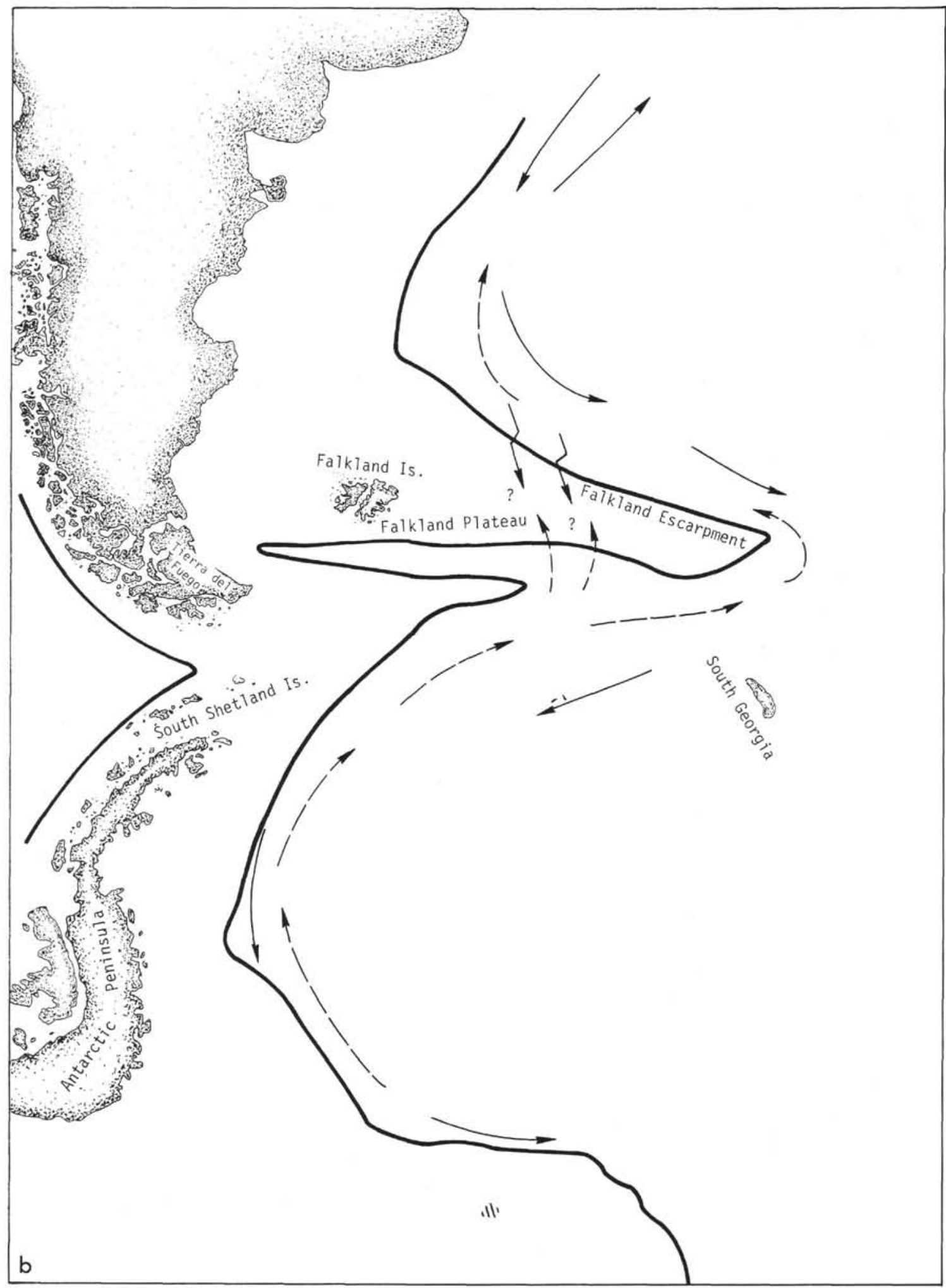

Figure 10. (Continued)

Antarctica. In Hayes, D.E., Frakes, L.A., et al., Initial Reports of the Deep Sea Drilling Project, Volume 28: Washington (U.S. Government Printing Office), p. 879 884 .
Allsopp, H.L. and Kolbe, P., 1965. Isotopic age determinations on the Cape granite and intruded Malmesbury sediments, Cape Peninsula, South Africa: Geochim. Cosmochim. Acta, v. 29, p. 1115-1130. 
Arctowski, H., 1895. Observations sur l'intérèt que présente l'exploration géologique des terres australes: Bull. Soc. Geol. France, Ser. 3, v. 23, p. 589-591.

Baker, A.H., 1924. Final report on geological investigations in the Falkland Islands: Port Stanley, Falkland Islands (Government Printers).

Baldwin, B., Coney, P.J., and Dickinson, W.R., 1974. The dilemma of a Cretaceous time scale and ratio of sea-floor spreading: Geology, v. 2, p. 267-270.

Barazangi, M. and Dorman, J., 1969. World seismicity maps compiled from ESSA Coast and Geodetic Survey epicenter data, 1961-1967: Seism. Soc. Am. Bull., v. 59, p. 369-380.

Barker, P.F., 1970. Plate tectonics in the Scotia Sea region: Nature, v. 228 , p. 1293-1296-

1972. Magnetic lineations in the Scotia Sea. In Adie, R.J. (Ed.), Antarctic geology and geophysics: Oslo (Universitetsforlaget), p. 17-26.

, in press. The tectonic framework of Cenozoic volcanism in the Scotia Sea region-A review: Bull. Volc.

Barker, P.F. and Griffiths, D.H., 1972. The evolution of the Scotia Ridge and Scotia Sea: Phil. Trans. Roy. Soc. London, Ser. A, v. 271, p. 151-183.

Barrow, J., 1831. Introductory note (to an article on the Islands of Deception): Roy. Geograph. Soc., v. 1, p. 62.

Berggren, W.A., van Hinte, J.E., McKenzie, D.P., and Sclater, J.G., 1975. World-wide correlation of Mesozoic magnetic anomalies and its implications: Discussion: Geol. Soc. Am. Bull., v. 86, p. 267-269.

Bolli, H.M., Ryan, W.B.F., et al., 1975. Basins and margins of the eastern South Atlantic: Geotimes, v. 20, p. 22-24.

Bullard, E.C., Everett, J.E., and Smith, A.G., 1965. Fit of continents around Atlantic. In Blackett, P.M.S., Bullard, E.C., and Runcorn, S.K. (Eds.), A Symposium on Continental Drift: Phil. Trans. Roy. Soc. London, Ser. A, v. 258 , p. $41-75$.

Burns, R.E., Andrews, J.E., et al., 1973. Initial Reports of the Deep Sea Drilling Project, Volume 21: Washington (U.S. Government Printing Office).

Cingolani, C.A. and Varela, R., in press. Investigaciones geologicas y geochronologicas en el extremo sur de la Isla Gran Malvina, sector de Cabo Belgrano (Cabo Meredith), Islas Malvinas.

Craddock, C., 1964. The structural relation of East and West Antarctica. In Sun daram, R.K. (Ed.), Rock deformation and tectonics - Part IV: 2nd Intl. Geol. Cong., New Delhi, p. 278-292.

, 1974. Tectonic evolution of the Pacific margin of Gondwanaland. In Campbell, K.S.W. (Ed.), Gondwana geology: ANU Canberra, p. 609-618.

Craddock, C. and Hollister, C.D., in press. Geologic evolution of the southeast Pacific basin. In Craddock, C. and Hollister, C.D., et al., Initial Reports of Deep Sea Drilling Project, v. 35, Washington (U.S. Government Printing Office)

Dalziel, I.W.D., 1974. Evolution of the margins of the Scotia Sea. In Burk, C.A. and Drake, C.L. (Eds.), The geology of continental margins: New York (Springer-Verlag), p. 567579.

in press. Structural studies in the Scotia Arc: the "basement" geology of the South Shetland Islands: Antarctic J. U.S.

Dalziel, I.W.D. and Cortés, R., 1972. The tectonic style of the southernmost Andes and the Antarctandes: 24th Intern. Geol. Congr. Proc., Montreal, Can., sec. 3, p. 316-327.

Dalziel, I.W.D. and Elliot, D.H., 1971. The evolution of the Scotia Arc: Nature, v. 233, p. 246-252.

1973. The Scotia Arc and Antarctic margin. In Stehli, F.H. and Nairn, A.E.M. (Eds.), The ocean basins and their margins: I. The South Atlantic: New York (Plenum Publishing), p. 171-245.

Dalziel, I.W.D. and Palmer, K.F., in press. Progressive deformation and orogenic uplift at the southern extremity of the Andes: Geol. Soc. Am. Bull.

Dalziel, I.W.D., Caminos, R., Palmer, K.F., Nullo, F., and Casanova, R., 1974a. Southern extremity of the Andes: the geology of Isla de los Estados, Argentine Tierra del Fuego: Am. Assoc. Petrol. Geol. Bull., v. 58, p. 2502-2512.

Dalziel, I.W.D., de Wit, M.J., and Palmer, K.F., 1974b. Fossil marginal basin in the southern Andes: Nature, v. 250 , p. $291-294$.

Dalziel, I.W.D., de Wit, M.J., and Ridley, W.I., 1975a. Structure and petrology of the Scotia Arc and the Patagonian Andes: R/V Hero Cruise 75-4: Antarctic J. U.S., v. X, p. 307-310.

Dalziel, I.W.D., de Wit, M.J., and Stern, C.R., 1975b. Structural and petrologic studies in the Scotia Arc: Antarctic J. U.S., v. X, p. 180-182.

Dalziel, I.W.D., Dott, R.H., Jr., Winn, R.D., Jr., and Bruhn, R.L., 1975c. Tectonic relations of South Georgia Island to the southernmost Andes: Geol. Soc. Am. Bull., v. 86, p. 1034-1040.

Davey, F.J., 1972. Gravity measurements over Burdwood Bank: Mar. Geophys. Res., v. 1, p. 428-435.

Denton, G.H., Armstrong, R.L., and Stuiver, M., 1971. The late Cenozoic glacial history of Antarctica. In Turekian, K.K. (Ed.), The late Cenozoic glacial ages: New Haven (Yale University Press), p. 267-306.

de Wit, M.J., in press. Evolution of the Scotia Arc: key to the reconstruction of southwest Gondwanaland: Tectonophysics.

Dingle, R.V., 1973. Post-Paleozoic stratigraphy of the eastern Agulhas Bank, South African continental margin: Marine Geol., v. 15, p. 1-23.

Dingle, R.V. and Scrutton, R.A., 1974. Continental breakup and the development of post-Paleozoic sedimentary basins around southern Africa: Geol. Soc. Am. Bull., v. 85, p. $1467-1474$.

Drewry, D.J., 1975. Initiation and growth of the East Antarctic ice sheet: J. Geol. Soc. (London), v. 131, p. 255-273.

Du Toit, A.L., 1937. Our wandering continents: Edinburgh (Oliver and Boyd).

Elliot, D.H., 1972. Aspects of Antarctic geology and drift reconstructions. In Adie, R.J. (Ed.), Antarctic geology and geophysics: Oslo (Universitetsforlaget), p. 849-858. 1975. Tectonics of Antarctica: a review: Am. J. Sci., v. 275 A, p. $45-106$.

Elliot, D.H. and Watts, D.R., 1974. The nature and origin of volcaniclastic material in some Karroo and Beacon rocks: Geol. Soc. South Africa Trans., v. 77, p. 109-111.

Emery, K.O., 1960. The sea off southern California: New York (John Wiley and Sons).

Emery, K.O., Uchupi, E., Bowen, C.O., Phillips, J., and Simpson, E.S.W., 1975. Continental margin off Western Africa: Cape St. Francis (South Africa) to Walvis Ridge (South-West Africa): Am. Assoc. Petrol. Geol. Bull., v. 59 , p. $3-59$.

Ewing, M. and Lonardi, A.G., 1971. Sediment transport and distribution in the Argentine Basin. 5. Sedimentary structure of the Argentine Margin Basin, and related Provinces: Physics and chemistry of the earth, v. VIII, p. 125-251.

Ewing, J.I., Ludwig, W.J., Ewing, J., and Eittreim, S.L., 1971. Structure of the Scotia Sea and Falkland Plateau: J. Geophys. Res., v. 76, p. 7118-7137.

Forsyth, D.W., 1975. Fault plane solutions and tectonics of the South Atlantic and Scotia Sea: J. Geophys. Res., v. 80, p. 1381-1604. 
Foster, R.J., 1974. Eocene echinoids and the Drake Passage: Nature, v. 249, p. 751.

Frakes, L.A. and Kemp, E.M., 1973. Paleogene continental positions and evolution of climate. In Tarling, D.H. and Runcorn, S.K. (Eds.), Implications of continental drift to the earth sciences, v. 1: London and New York (Academic Press), p. 535-558.

Fuller, A.O., 1974. The occurrence of larmontite in strata of the Karroo System, South Africa: In Hargerson, S.H. (Ed.), Proc., Papers Second Gondwana Symp.: Pretoria, South Africa CSIR, p. 455-456.

Gill, A.R. and Bryan, K., 1971. Effects of geometry on the circulation of a three-dimensional southern-hemisphere ocean model: Deep-Sea Res., v. 18, p. 685-721.

Goodell, H.G., 1973. Marine sediments of the Southern Ocean. In Bushness, V.C. (Ed.), Antarctic Map Folio Series: New York (Am. Geogr. Soc.), Folio 17.

Gordon, A.L., 1971. Oceanography of Antarctic waters. In Reid, J.L. (Ed.), Antarctic Oceanology I, Antarctic Res. Ser., v. 15: Washington (Am. Geophys. Union).

Greenway, M.E., 1972. Geology of the Falkland Islands: Br. Antarctic Surv. Sci. Rept, no. 76, 42 p.

Halpern, M., 1972. Geochronologic evolution of southern South America. In Int. Symp. Carboniferous and Permian Systems in South America Proc.: Sao Paulo, Brazil (Acad. Braziliera de Ciencias), p. 77-88.

Haughton, S.H., 1969. Geological history of southern Africa: Geol. Soc. S. Africa, Cape Town.

Hawkes, D.D., 1962. The structure of the Scotia Arc: Geol. Mag., v. 99, p. 85-91.

Hayes, D.E. and Frakes, L.A., 1975. General synthesis, Deep Sea Drilling Project Leg 28. In Hayes, D.E., Frakes, L.A., et al., Initial Reports of the Deep Sea Drilling Project, Volume 28, Washington (U.S. Government Printing Office), p. 919-942.

et al., 1975. Initial Reports of the Deep Sea Drilling Project, Volume 28: Washington (U.S. Government Printing Office).

Heirtzler, J.R., Dickson, G.O., Herron, E.M., Pitmas, W.C., III, and Le Pichon, X., 1968. Marine magnetic anomalies, geomagnetic field reversals, and motions of the ocean floor and continents: J. Geophys. Res., v. 73, p. 2119-2136.

Hollister, C.D., Ewing, J.I., et al., 1972. Initial Reports of the Deep Sea Drilling Project, Volume 11: Washington (U.S. Government Printing Office).

Hurley, P.M., de Almeida, F.F.M., Melcher, G.C., Cordani, V.G., Rand, J.R., Kawashita, K., Vandaros, P., Pinson, W.H., and Fairbairn, H.W., 1967. Test of continental drift by comparison of radiometric ages: Science, v. 157, p. 495-500.

Kemp, E.M., Frakes, L.A., and Hayes, D.E., 1975. Paleoclimatic significance of diachronous biogenic facies, Leg 28, Deep Sea Drilling Project. In Hayes, D.E., Frakes, L.A., et al., Initial Report of Deep Sea Drilling Project, Volume 28: Washington (U.S. Government Printing Office), p. 909-918.

Kennett, J.P., Houtz, R.E., et al., 1974. Initial Reports of the Deep Sea Drilling Project, Volume 29: Washington (U.S. Government Printing Office).

Kennett, J.P., Burns, R.E., Andrews, J.E., Churkin, M., Jr., Davies, T.E., Dumitrica, P., Edwards, A.R., Galehouse, J.S., Pauchan, G.H., and van der Lingen, G.J., 1972. Australia-Antarctic continental drift, paleocirculation changes and Oligocene deep-sea erosion: Nature Phys. Sci., v. 239, p. 51-55.

Kent, P.E., 1974. Continental margin of East Africa-a region of vertical movement. In Burk, C.A. and Drake,
C.L. (Eds.), the geology of continental margins: New York (Springer-Verlag).

Kinsman, D.J.J., 1975. Sedimentary history of trailing continental margins. In Fischer, A.G. and Judson, S. (Eds.), Petroleum and global tectonics: Princeton (Princeton University Press), p. 83-128.

Ladd, J.W., 1975. Unpublished Ph.D. Thesis, Columbia University, New York.

Ladd, J.W., Dickson, G.O., and Pitman, W.C., III, 1973. The age of the South Atlantic. In Nairn, A.E.M. and Stehli, F.G. (Eds.), The ocean basins and margins: the South Atlantic: New York (Plenum Press), p. 555-573.

Lancelot, Y., Hathaway, J.C., and Hollister, C.D., 1972. Lithology of sediments from the western North Atlantic, Leg 11, Deep Sea Drilling Project. In Hollister, C. D., Ewing, J.I., et al., Initial Reports of Deep Sea Drilling Project, Volume 11: Washington (U.S. Government Printing Office), p. 901-949.

Lancelot, Y., Seibold, E., et al., 1975. The eastern North Atlantic: Geotimes, v. 20, p. 18-21.

Larson, R.L. and Hilde, T.W.C., 1975. A revised time scale of magnetic reversals for the early Cretaceous, Late Jurassic: J. Geophys. Res., v. 80, p. 2586-2594.

Larson, R.L. and Ladd, J.W., 1973. Evidence for the opening of the South Atlantic in the Early Cretaceous: Nature, v. 246 , p. $209-212$.

Larson, R.L., Moberly, R., et al., 1975. Initial Reports of the Deep Sea Drilling Project, Volume 32: Washington (U.S. Government Printing Office).

Larson, R.L. and Pitman, W.C., III, 1972. World-wide correlation of Mesozoic magnetic anomalies, and its implications: Geol. Soc. Am. Bull., v. 83, p. 3645-3662. 1975. World-wide correlations of Mesozoic magnetic anomalies and its implications: Reply: Geol. Soc. Am. Bull., v. 86, p. 270-272.

Le Pichon, X., Eittreim, S.L., and Ludwig, W.L., 1971. Sediment transport and distribution in the Argentine Basin. I. Antarctic bottom current passage through the Falkland Fracture zone: Physics and chemistry of the earth, v. VIII: Exeter (Pergamon Press), p. 1-28.

Ludwig, W.J., Ewing, J.I., and Ewing, M., 1968. Structure of Argentine continental margin: Am. Assoc. Petrol. Geol. Bull., v. 52, p. 2337-2368.

Luyendyk, B.P. and Davies, T.A., 1974. Results of DSDP Leg 26 and the geologic history of the southern Indian Ocean. In Davies, T.A., Luyendyk, B.P., et al., Initial Reports of the Deep Sea Drilling Project, Volume 26: Washington (U.S. Government Printing Office), p. 909943.

Martin, H., 1974. Structural and paleogeographical evidence for an upper Paleozoic sea between southern Africa and South America. In Campbell, K.S.W., Gondwana geology: Canberra (ANU), p. 37-51.

Natland, M.L., Gonzalez, E., Canon, A., and Ernst, M., 1974. A system of Stages for Correlation of Magallanes Basin Sediments: Geol. Soc. Mem. 139, 126 p.

Parker, R.L. and Oldenburg, D.W., 1973. Thermal model of ocean ridges: Nature, v. 242, p. 137-139.

Perch-Nielsen, K., Supko, P.T., et al., 1975. Leg 39 examines facies changes in South Atlantic: Geotimes, v. 20, p. 2628.

Rivana, S. and Cortés, R., 1976. Note on the presence of the lawsonite-sodic amphibole association on Smith Island, South Shetland Islands, Antarctica: Earth Planet. Sci. Lett., v. 29, p. 34-36.

Savin, S.M., Douglas, R.G., and Stehli, F.G., 1975. Tertiary marine paleotemperatures: Geol. Soc. Am. Bull., v. 86, p. $1499-1510$. 
Schlanger, S.O., Jackson, E., et al., 1976. Initial Reports of the Deep Sea Drilling Project, Volume 33: Washington (U.S. Government Printing Office).

Scott, K.M., 1966. Sedimentology and dispersal pattern of a Cretaceous flysch sequence, Patagonian Andes, southern Chile: Am. Assoc. Petrol. Geol. Bull., v. 50, p. 72-107.

Scrutton, R.A., 1973. Structure and evolution of the sea floor south of South Africa: Earth Planet. Sci. Lett., v. 19, p. 250-256.

Shackleton, N.J. and Kennett, J.P., 1975. Paleotemperative history of the Cenozoic and the initiation of Antarctic glaciation: Oxygen and Carbon isotope analyses in DSDP Sites 277, 279 and 281. In Kennett, J.P., Houtz, R.E., et al., Initial Reports of the Deep Sea Drilling Project, Volume 29: Washington (U.S. Government Printing Office), p. 743-756.

Smellie, J.L. and Clarkson, P.D., 1975. Evidence for preJurassic subduction in western Antarctica: Nature, v. 258, p. 701-702.

Smith, A.G. and Hallam, A., 1970. The fit of the southern continents: Nature, v. 225, p. 139-144.

Suarez, M., 1976. Plate tectonic model for southern Antarctic Peninsula: Geology, v. 4, p. 211-214.
Theron, J.C., 1975. Sedimentological evidence for the extension of the African continent southwards during the Late Permian-Early Triassic times. In Campbell, K.S.W. (Ed.), Gondwana geology: Canberra (ANU), p. 61-71.

Tucholke, B., Vogt, P., et al., 1975. Glomar Challenger drills in the North Atlantic: Geotimes, v. 20, p. 18-21.

Urien, L.M. and Zambrano, J.J., 1973. The geology of the basins of the Argentine continental margin and Malvinas Plateau. In Nairn, A.E.M. and Stehli, F.G. (Eds.), The ocean basins and margins, I: The South Atlantic: New York (Plenum Press), p. 135-164.

Van Andel, T.H., 1975. Mesozoic/Cenozoic calcite compensation depth and the global distribution of calcareous sediments: Earth Planet. Sci. Lett., v. 26, p. 187-194.

Veevers, J.J., Heirtzler, J.R., et al., 1974. Initial Reports of the Deep Sea Drilling Project, Volume 27: Washington (U.S. Government Printing Office).

Weissel, J. and Hayes, D.E., 1972. Magnetic anomalies in the southeast Indian Ocean. In Hayes, D.E. (Ed), Antarctic Oceanology II: the Australian - New Zealand Sector: Antarctic Res. Ser., v. 19: Washington (Am. Geophys. Union), p. 165-196. 